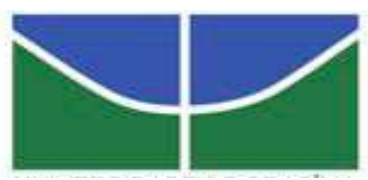

UNIVERSIDADE DE BRASÍLIA

Centro de Excelência em Turismo

Pós-graduação Lato Sensu

Curso de Especialização em Gestão de Negócios em Turismo

\title{
ATIVIDADE TURÍSTICA SUSTENTÁVEL NA APA DE SANTO ANTÔNIO - SANTA CRUZ CABRÁLIA - BA.
}

Sheila Silvyane Silveira Rocha

Sônia Wiedmann

Doutora

Brasília - 2007 


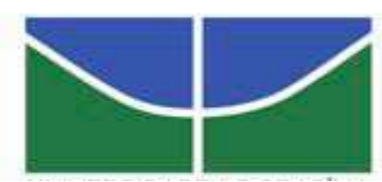

UNIVERSIDADE DE BRASÍLIA

Centro de Excelência em Turismo

Pós-graduação Lato Sensu

Curso de Especialização em Gestão de Negócios em Turismo

\title{
ATIVIDADE TURÍSTICA SUSTENTÁVEL NA APA DE SANTO ANTÔNIO - SANTA CRUZ CABRÁLIA - BA.
}

\author{
Sheila Silvyane Silveira Rocha
}

Sônia Wiedmann

Doutora

Monografia apresentada ao Centro de Excelência em turismo - CET, da Universidade de Brasília - UnB, como requisito parcial à obtenção do grau de Especialista em Gestão de Negócios em Turismo. 
Rocha, Sheila Silvyane Silveira.

A Atividade Turística Sustentável na APA de Santo Antônio - Santa Cruz Cabrália- Ba. / Sheila Silvyane Silveira Rocha. - Brasília, 2007.

$x, 65$ fij.

Monografia (Gestão de Negócios em Turismo) Universidade de Brasília, Centro de Excelência em Turismo, 2007.

Orientador (a): Sônia Wiedmann.

1. Atividade Turística. 2. Sustentável. 3. APA. 4. Santo Antônio. 5. Santa Cruz Cabrália - Ba. I Título. 


\section{UNIVERSIDADE DE BRASÍLIA \\ Centro de Excelência em Turismo \\ Pós-graduação Lato sensu \\ Curso de Especialização em Gestão de Negócios em Turismo}

Sheila Silvyane Silveira Rocha

Aprovado por:

Sônia Wiedmann

lara Brasileiro

Rogério Dias

Monografia apresentada ao Centro de Excelência em turismo - CET, da Universidade de Brasília - UnB, como requisito parcial à obtenção do grau de Especialista em Gestão de Negócios em Turismo.

Brasília, de de20 


\section{DEDICATÓRIA}

Dedico este trabalho, com todo amor e carinho à pessoa mais importante e especial da minha vida. Pessoa essa, que me educou e me ensinou a percorrer os caminhos corretos da vida. Dedico a ti mãe, que em nenhum momento mediu esforços para me ajudar a alcançar os meus objetivos. Amo-ti demais! A Senhora é a melhor mãe que existe e eu tenho o maior orgulho por ser tua filha! 


\section{AGRADECIMENTOS}

Inicio os meus agradecimentos ao Supremo Deus Criador de todas as coisas.

Agradeço especialmente a minha mãe pelo seu amor, carinho, esforço e dedicação. Agradeço também toda a minha família pelo carinho e apoio.

A minha amiga Tia Jô e sua família por ter me acolhido e hoje fazerem parte da minha vida.

Ao amigo irmão Thadeu que participou dessa caminhada junto comigo, onde pudemos nos acolher e dividir todas as dificuldades. Adoro a cumplicidade e necessidade que temos um com o outro, você é o amigo que fez e faz parte de todos os melhores e especiais momentos de minha vida. Amo-ti demais mãe!

Aos meus amigos e colegas do curso que participaram dessa importante fase da minha vida. Em especial a Carol e Luciene que me acolheram desde o início.

Aos amigos Rodrigo, Kellen, Wal, Pity, Tate, Priscila, Palloma e Ana Paula que tornaram-se muito especiais, agradeço de coração pelo carinho e alegrias que compartilhamos juntos.

As minhas amigas Cau, Chulo, Lu e Lia por serem tão confiáveis e importantes. Mesmo longe de vocês, sou capaz de sentir o grande apoio e força que depositam para que eu consiga alcançar e vencer os obstáculos que me são propostos. Amo vocês demais. Muito obrigada pela amizade, amor e carinho! Saudades!

Agradeço ao Diego, Fernanda e Hiran que na reta final deste trabalho contribuíram de forma muito atenciosa.

Agradeço a comunidade de Santo Antônio pela receptividade.

A minha orientadora, professores e funcionários do CET. Em especial ao Luís pela gentileza e apoio sempre. 


\section{RESUMO}

O objetivo deste trabalho científico é verificar a possível atuação do turismo sustentável na APA - Área de Proteção Ambiental de Santo Antônio, povoado este que está localizado no extremo sul da Bahia, na Costa do Descobrimento, no município de Santa Cruz Cabrália. A vila Santo Antônio possui cerca de 1820 habitantes e conta com uma enorme faixa litorânea, além de dispor de outros atrativos ecoturísticos naturais e culturais. Situada dentro de uma APA, possui riquezas naturais intocadas muito importantes para que o avanço turístico possa acontecer. De acordo com dados adquiridos durante a pesquisa in loco, através dos métodos descritivo, quantitativo e documental e também das pesquisas exploratória, explicativa e bibliográfica, verificou-se o possível desenvolvimento sustentável, mas é algo que precisa ser bem diagnosticado e preparado para que o desempenho da atividade turística aconteça cautelosamente, sem causar impactos negativos aos ambientes naturais e culturais. Constatou-se a existência do Plano de Manejo da APA, o qual é fundamental para a sustentabilidade da APA. Os planos voltados para o crescimento do turismo local, precisam estar em consonância com o Plano de Manejo, no intuito de preservar as zonas caracterizadas dentro da APA para o uso sustentável. A intenção do desenvolvimento turístico no povoado Santo Antônio é proporcionar uma melhor qualidade de vida a comunidade local através da geração de renda e emprego que a atividade poderá dispor. A comunidade de Santo Antônio possui uma vida simples e sofrida devido às dificuldades já encontradas por falta de emprego. A disponibilidade de ocupações local favorecerá aos nativos que não mais precisarão sair do seu habitat em busca de emprego em outras localidades. Com a atuação do turismo, a oportunidade de se ter uma vida mais justa e digna será evidente para o bem-estar da população.

PALAVRAS-CHAVE: turismo, Área de Proteção Ambiental, sustentabilidade. 


\begin{abstract}
The aim of this work is to verify the possible implementation of sustainable tourism at Santo Antonio's EPA (Environment Protection Area), a village located at the southern Bahia, in the city of Santa Cruz Cabrália. The village of Santo Antonio has about 1.820 inhabitants and counts with a long coastline, besides other natural and cultural ecotourism attractions. Situated inside an EPA, it owns preserved natural resources which are very important for touristic development. According to data obtained during the in loco research, through documental, descriptive quantitative methods and also explorative, explicative and bibliographical researches, it was verified the possible sustainable development, but it is something that needs to be checked and prepared so that the perfomance of the touristic activity happens cautiously, without causing negative impact to the natural and cultural environment. It was verified the existence of the EPA's Handling Plan, which is fundamental for EPA's sustainability. The local tourism growth plans, need to be in accordance with the Handling Plan, in order to preserve the zones characterized inside the EPA for the sustainable use. The purpose for the tourism development in the Santo Antonio village is to provide a better life quality to the local community through incoming and job generation which the activity will be able to provide. The community of Santo Antonio has a simple and hard way of life due to the difficulties already found caused by the lack of employment. Local job availability will benefit natives who will not need to leave their habitat to look for a job in other areas. With the tourism perfomance, the opportunity of having a better life will be evident for the population welfare.
\end{abstract}

KEY WORDS: Tourism, Environment Protection Area, sustainability. 


\section{LISTA DE ILUSTRAÇÕES}

Ilustração 1 - Mapa de Localização da APA de Santo Antônio................................02

Ilustração 2 - Foto Vista Aérea do Povoado Santo Antônio..................................28 


\section{LISTA DE ABREVIATURAS E SIGLAS}

APA: Área de Proteção Ambiental

CRA: Centro de Recursos Ambientais

IBAMA: Instituto Brasileiro do Meio Ambiente

OMT: Organização Mundial do Turismo

PRODETUR: Programa de Desenvolvimento Turístico da Bahia

SNUC: Sistema Nacional de Unidade de Conservação

SUDETUR: Secretaria da Cultura e Turismo da Bahia

TCC: Trabalho de Conclusão de Curso

ZAE: Zona de Atividades Econômicas Diversificadas

ZAP: Zona de Agropecuária

ZAT: Zona de Apoio Turístico

ZER: Zona de Expansão Urbana Rarefeita

ZEU: Zona de Expansão Urbana Prioritária

ZEU-E1: Zona de Expansão Urbana Especial 1

ZEU-E1: Zona de Expansão Urbana Especial 2

ZEU-E1: Zona de Expansão Urbana Especial 3

ZIR: Zona de Intervenção Restrita

ZME: Zona de Manejo Especial

ZOM: Zona da Orla Marítima

ZOR: Zona de Ocupação Rarefeita

ZOR-E: Zona de Ocupação Rarefeita Especial

ZPR: Zona de Proteção Rigorosa

ZPR-E: Zona de Proteção Rigorosa Especial

ZPVS: Zonas de Preservação da Vida Silvestre 


\section{SUMÁRIO}

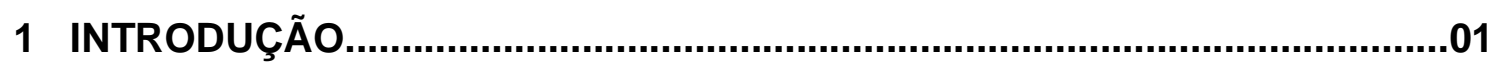

1.1 Contextualização........................................................................ 03

1.2 Problematização e Justificativa......................................................... 04

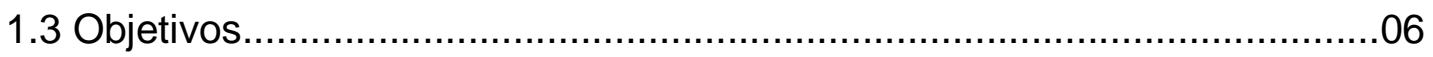

1.3.1 Objetivo Geral:.............................................................. 06

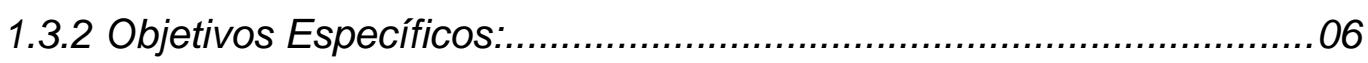

2 REFERENCIAL TEÓRICO......................................................................... 07

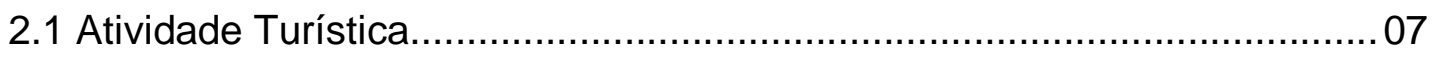

2.2 Desenvolvimento Integrado do Turismo em APA: Rumo a

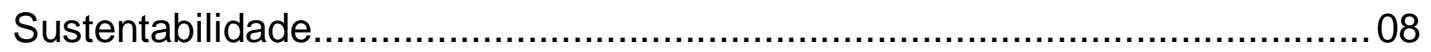

2.3 A Importância do Planejamento para a Atividade Turística....................... 12

2.3.1 Planejar é preciso................................................................... 17

3 METODOLOGIA.........................................................................................20

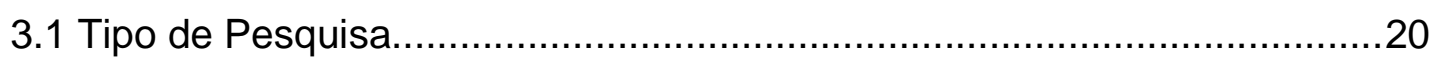

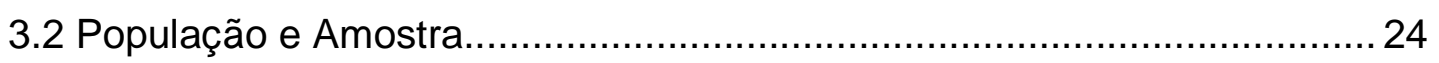

3.3 Instrumento de Coleta de Dados..........................................................24

3.4 Processo de Coleta de Dados...............................................................25

3.5 Análise dos Dados..................................................................... 26

4 APRESENTAÇÃO E ANÁLISE DOS RESULTADOS....................................27

4.1 Anseios dos moradores e a realidade atual de Santo Antônio.................. 27

4.2 Aproveitamento dos Recursos Naturais para a Possível Atuação do

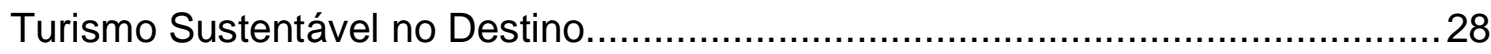

4.3 A Importância do Turismo no Povoado com o Uso Sustentável de sua APA para o Bem-estar da Comunidade Local............................................................ 30

4.4 Esclarecimento da População Através de Educação Ambiental Sobre a

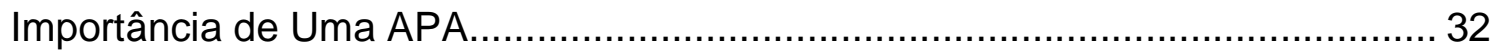


4.5 Importância da Inclusão da Atividade Turística no Plano de Manejo da APA

Para Melhor Desempenho do Turismo Dentro da APA de Santo Antônio

4.6 Incentivar a Preservação e Conservação dos Recursos Naturais e da Identidade Cultural dos Nativos

5 CONSIDERAÇÕES FINAIS.................................................................. 38

REFERÊNCIAS BIBLIOGRÁFICAS............................................................. 40

APÊNDICES.

APÊNDICE A - Entrevista realizada ao Secretário do Meio Ambiente, Sr. Euclides

Senna, sobre a APA de Santo Antônio - Ba.

APÊNDICE B - Entrevista realizada ao morador voluntário Sr. Antônio Barbosa Lacerda, sobre a preservação da APA de Santo Antônio - Ba. .50

APÊNDICE C - Entrevista realizada em 2005 por essa pesquisadora sobre o povoado de Santo Antônio, ao Sr. prefeito de Santa Cruz Cabrália - Ba, Sr. José Ubaldino Alves Pinto.

APÊNDICE D - Entrevista realizada em 2005 por essa pesquisadora com a secretária do turismo de Santa Cruz Cabrália - Ba, Sra. Amale Abou Jokh, sobre o turismo em Santo Antônio.

ANEXOS

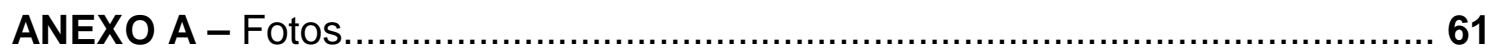

ANEXO B - Mapa do Plano de Manejo da APA de Santo

Antônio. .65 


\section{1- INTRODUÇÃO}

A atividade turística é um fenômeno que está crescendo cada vez mais em todo o mundo. É muito importante para o desenvolvimento sócio-econômico de cidades, estados e países, capaz de gerar renda e emprego, e muitas vezes surge como a única solução para a sobrevivência de várias localidades.

O turismo é essencial para o desenvolvimento mundial, mas precisa acontecer de forma sustentável, através de um planejamento adequado. Considerado um setor que se expandiu rapidamente, o turismo cria expectativas para que áreas ainda não desenvolvidas sejam descobertas e exploradas, tornando-se meio de sobrevivência para a comunidade e outros que trabalham direto ou indiretamente nesse setor.

É possível observar o quanto a atividade turística significa para o bem-estar da população mundial, pois é através dela que ocorre a expansão da cultura entre os povos e o crescimento entre as nações. Mas, para que esse fenômeno se desenvolva em uma localidade, é necessário que a região disponha de atrativos turísticos diversificados, esteja em estado de conservação, ofereça infra-estrutura adequada (hospedagem, fácil acesso aos atrativos, postos de informações turísticas, estrutura urbana adequada, entre outros), enfim, que possa chamar a atenção dos visitantes, proporcionando a eles maior satisfação. Dessa forma, torna-se indispensável a elaboração de um planejamento de acordo a legislação ambiental, pois, somente através desses requisitos importantes e essenciais o turismo poderá se desenvolver sustentavelmente num destino.

Seabra (2001, p.30) destaca que:

a lei $\mathrm{n}$ - 6.513, de 1997, regulamentada pelo decreto $\mathrm{n}$ - 86.176 , de 6/7/1981, que dispõe sobre Áreas Locais de Interesse Turístico $(\mathrm{ALIT})^{1}$, "todos os planos e programas turísticos deverão assegurar a preservação e valorização do patrimônio cultural e natural e estabelecer normas de uso e ocupação do solo".

\footnotetext{
${ }^{1}$ Correspondem a trechos contínuos do território nacional, inclusive suas áreas territoriais, a serem preservados e valorizados no sentido natural e cultural, e destinados à realização de planos e projetos de desenvolvimento turístico.
} 
Diante dessa contextualização, da busca por um desenvolvimento sustentável e das oportunidades de crescimento que o turismo proporciona a um destino, destaca-se o povoado Santo Antônio que está situado no extremo sul da Bahia, no município de Santa Cruz Cabrália, o qual possui cerca de 1.820 habitantes e tem o privilégio de estar situado dentro de uma Área de Proteção Ambiental - APA de Santo Antônio, que foi criada pelo Decreto Estadual № 3.143, de 31 de agosto de 1994, possuindo uma área de 23.000 ha, um conjunto de atrativos ecoturísticos identificados pelo Plano de Manejo, a qual não deve ser devastada.

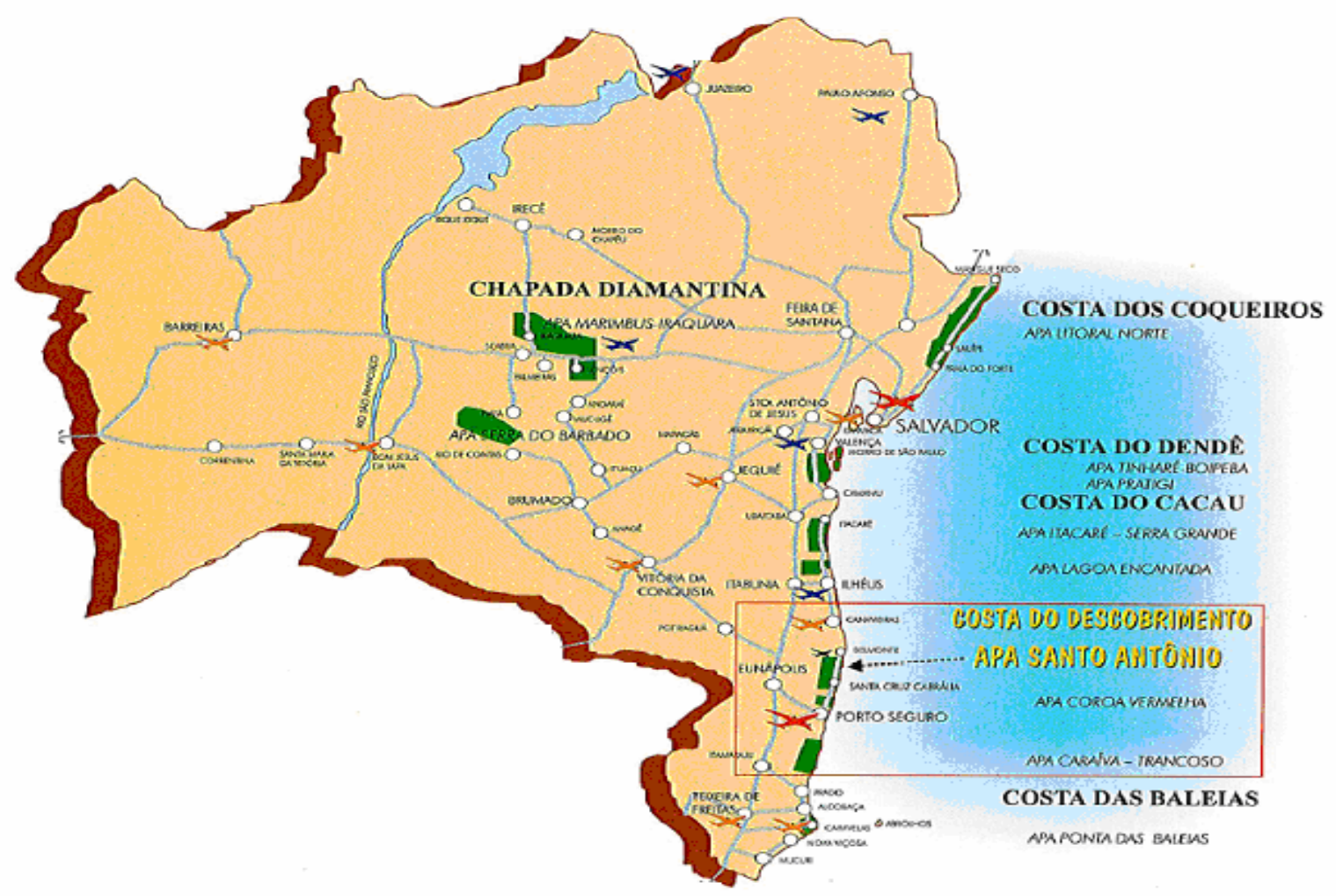

Ilustração I: Mapa para identificação da APA de Santo Antônio Fonte: Plano de Manejo da APA de Santo Antônio, 1999.

Além de Santo Antônio, o município de Santa Cruz Cabrália dispõe de mais três povoados (Coroa Vermelha, Santo André e Guaiú) que juntamente com os outros municípios da região (Porto Seguro, Arraial D’Ajuda, Trancoso, Caraíva, Mogiquissaba e Belmonte) compõem o pólo turístico da Costa do Descobrimento.

A Costa do Descobrimento é uma região muito rica por apresentar belezas naturais diversificadas, além de ser um marco na história da descoberta do Brasil. Por estar inserido dentro dessa região, Santo Antônio 
apresenta uma certa vantagem, pois essa questão poderá facilitar o conhecimento e a localização do destino para os turistas.

Conforme as informações obtidas sobre APA e o povoado Santo Antônio, a presente pesquisa busca estudar a possível atuação da Atividade Turística Sustentável na APA de Santo Antônio - Santa Cruz Cabrália BA.

\subsection{Contextualização}

Tendo em vista a importância do desenvolvimento turístico sustentável num destino por proporcionar o crescimento econômico e melhor qualidade de vida aos nativos, evidencia-se aqui nesse trabalho que o povoado de Santo Antônio no município de Cabrália - BA, dispõe de oportunidades para a atuação desse setor que tanto está crescendo mundialmente.

Dando continuidade a um estudo realizado pela pesquisadora, ROCHA, Sheila Silvyane Silveira (2005), em complemento ao TCC pela Faculdade de Tecnologia e Ciências - Vitória da Conquista - Bahia, no curso de Turismo, sobre Santo Antônio sugerindo o desenvolvimento do turismo sustentável no povoado, verificou-se através de pesquisas realizadas ao local que Santo Antônio possui potencial para atuação da atividade turística e que a comunidade está de acordo com o desenvolvimento desse segmento.

Os atrativos culturais e locacionais destacados pela comunidade local, foram apontados através de um questionário e entrevistas realizadas para o desempenho do turismo na região, destacaram-se: Aldeia Indígena Mata Medonha, Festa de Santo Antônio, Festa de São Sebastião, Praia Ponta de Santo Antônio, Parque Ecológico O Santuário, Estátua de Santo Antônio, Rio Santo Antônio, Jangada - Ponto de encontro dos visitantes e Mangue. 
Para dar continuidade a esse estudo deverá ser levado em conta que o povoado está situado dentro de uma Área de Proteção Ambiental -APA, o que requer um estudo mais cuidadoso sobre o tema.

Santo Antônio é um local pacato e muito conservado em suas belezas naturais, onde vive uma comunidade humilde e acolhedora, cuja fonte de subsistência é principalmente a pesca e a atividade extrativista de coleta de piaçava e côco, os nativos desejam muito o progresso em seu local residente. Mas esse progresso precisa acontecer de forma sustentável através de um planejamento que vise principalmente a preservação e conservação dos ambientes natural, cultural e social.

\subsection{Problematização e Justificativa}

O povoado Santo Antônio que faz parte do município de Santa Cruz Cabrália e está localizado dentro de uma APA, a de Santo Antônio na Costa do Descobrimento, a qual dispõe de atrativos naturais que podem ser utilizados para o ecoturismo. Ainda não há desempenho da atividade no local, pôde-se constatar o potencial do povoado para atuação da atividade turística através da pesquisa realizada em 2005, a qual terá continuidade nesse estudo científico para melhor evidenciar o desenvolvimento do turismo sustentável dentro da APA.

A vila Santo Antônio juntamente com os povoados de Coroa Vermelha, Santo André e Guaiú fazem parte do município de Santa Cruz Cabrália - Ba. Dentre esses, Santo Antônio ainda não se desenvolveu turisticamente.

A comunidade do povoado tem sua economia através da pesca, da confecção de artesanato pelo uso da piaçava e da venda de cocos. O turismo ainda não é considerado um meio de sobrevivência local.

Em relação ao calendário cultural, foi possível retratar através das entrevistas que o povoado Santo Antônio comemora sua festa de Santo Antônio no mês junho e a festa de São Sebastião em Janeiro. São festas simples ainda, comemoradas apenas pelos moradores do povoado. 
Em Santo Antônio ainda não existem meios de hospedagem, porém, no seu entorno existem locais, onde os turistas podem se hospedar, como pousadas, hotel fazenda e resorts. A localidade é pobre de infra-estrutura para receber turistas.

A intenção é tornar o povoado conhecido através de suas belezas naturais dando ênfase à atividade turística como fator de desenvolvimento econômico e sustentável. A APA de Santo Antônio proporciona a ele uma imensa riqueza em atrativos naturais intocados, o que chamou a atenção para que uma pesquisa mais aprofundada fosse realizada sobre o local, a fim de estimular a iniciação e preparação de um planejamento para o desenvolvimento do turismo sustentável, podendo explorar esses atrativos de forma coerente, respeitando as suas características, e dessa forma, levar o crescimento para a comunidade e transformar esse destino num forte concorrente para o futuro mercado do ecoturismo.

Santo Antônio, um pequeno povoado rico em atrativos naturais, estabelecido dentro de uma APA, dispondo de uma comunidade simples que através do pouco trabalhado que lhe é proporcionado no dia-a-dia, busca com força e vontade o sustento da vida. Esse destino tem capacidade de adquirir o progresso, se desenvolver socialmente e economicamente através do turismo sustentável. Mas, há muito que fazer, pesquisar e planejar.

É preciso esclarecer a essa comunidade o seu valor, esclarecê-la, aos órgãos públicos e ao setor privado que o meio ambiente natural local que dispõe é muito importante para a sobrevivência da região e que necessita ser conservado de acordo a Legislação Ambiental e de que forma poderá ser planejado e desenvolvido dentro da APA, fomentando o progresso daquela localidade.

Diante dessas observações sobre o local, justifica-se aqui nesse estudo a fundamental necessidade e importância da continuidade da pesquisa científica (2005) para analisar melhor o turismo sustentável dentro da APA de Santo Antônio, a fim de propor um planejamento para usufruto dos atrativos disponíveis no local.

Santo Antônio é um povoado rico em atrativos naturais ecoturísticos que podem ser usufruídos no intuito de levá-lo ao progresso através da atividade turística sustentável. Portanto, torna-se possível a elaboração da seguinte questão de pesquisa: Será possível desenvolver um turismo sustentável 
dentro da APA de Santo Antônio como forma de levar o progresso ao povoado e garantir a sustentabilidade da comunidade?

\subsection{OBJETIVOS}

\subsubsection{Objetivo Geral:}

- Verificar a possibilidade de um desenvolvimento turístico sustentável na APA de Santo Antônio, visando o crescimento do povoado e a sustentabilidade da comunidade.

\subsubsection{Objetivos Específicos:}

- Avaliar o aproveitamento dos recursos naturais de forma sustentável para a possível atuação da atividade turística no destino;

- Relacionar a importância do turismo no povoado com o uso sustentável de sua APA para o bem-estar da comunidade local;

- Estimular o esclarecimento da população através de educação ambiental sobre a importância de uma APA;

- Propor a inclusão da atividade turística no plano de manejo da APA para melhor desempenho do turismo na APA de Santo Antônio;

- Incentivar a preservação e conservação dos recursos naturais e da identidade cultural dos nativos. 


\title{
2- REFERENCIAL TEÓRICO
}

\subsection{Atividade Turística}

A globalização tem se apresentado como um dos fatores para 0 desenvolvimento da atividade turística. Através da comunicação as pessoas adquirem uma abrangência de conhecimentos interligados entre os conceitos culturais, sociais, econômicos e ambientais que ocorrem em todo o mundo.

Segundo Rose (2002, p. 2):

\begin{abstract}
A atividade turística pressupõe a existência de um mercado turístico, caracterizado, de um lado, pela oferta - uma localidade receptora dotada de infra-estrutura e equipamentos especializados - e, de outro, pela demanda consumidora (turistas), representada pela qualidade de pessoas com disponibilidade financeira e tempo para viajar.
\end{abstract}

O turismo é uma atividade que proporciona mudanças na economia dos destinos, gera muito emprego para a população, mas, quando mal planejado, causa impactos negativos que chegam a ser irreversíveis, resultando assim o fracasso ao invés de maiores crescimentos. Ao contrário, quando o turismo é exposto da forma correta através do planejamento, este minimiza os impactos negativos, tornando-se uma grande fonte de riqueza ao gerar emprego e renda, ao preservar a cultura do povo, ao influenciar na melhoria da infra-estrutura local, entre outros meios que proporcionam melhor qualidade de vida para a comunidade.

De acordo a OMT (2003, p. 20) a definição do turismo está relacionada "as atividades de pessoas que viajam para lugares afastados de seu ambiente usual, ou que neles permaneçam por menos de um ano consecutivo, a lazer, a negócios ou por outros motivos".

O turismo é uma atividade socioeconômica muito visada por determinar elevados benefícios, capazes de atrair em cada localidade específica um grande número de turistas. O turismo está crescendo cada vez mais no mundo e tanto os países desenvolvidos quanto aos países em desenvolvimento contribuem nesse contexto, pois são emissores e receptores de turistas, estando estes dispostos a 
conhecer e a usufruir da diversidade de benefícios que o turismo oferece (OMT 1995).

Segundo Goeldner et el. (2002, p.338): "O turismo é um setor em crescimento e, embora esse crescimento possa apresentar alguma desaceleração em curto prazo, as perspectivas de longo prazo são boas”. É possível notar a importância do turismo como fonte de renda para muitas regiões, e como essa concepção é favorável para a sobrevivência da população.

Entretanto, existe a constatação de que o turismo não proporciona apenas benefícios, ele pode ocasionar conseqüências prejudiciais ao próprio desenvolvimento da atividade. Por esse motivo deve-se elaborar um planejamento sempre que se pensar em desenvolver o turismo numa localidade, buscar a sustentabilidade para preservar o ambiente que será usufruído pelo setor turístico.

\subsection{Desenvolvimento Integrado do Turismo em APA: Rumo a Sustentabilidade}

O turismo sustentável é muito importante para a preservação e conservação dos recursos naturais. Em se tratando de desenvolvimento turístico numa Área de Proteção Ambiental - APA, fica evidente o quanto esse assunto deve ser tratado cuidadosamente, através de planejamento e de acordo com as normas legais vigentes para a APA. Para iniciar um contexto tão delicado será necessário destacar a definição de APA, sobre a sua importância e o seu papel em relação ao ambiente natural e qual o órgão responsável para a implantação de uma APA.

O Sistema Nacional de Unidades de Conservação da Natureza - SNUC foi instituído pela Lei n-9 9.985, de 18 de Julho de 2000 (ver anexo F) com base no artigo 225 da Constituição Federal o qual trata da proteção ambiental. O SNUC prevê dois grupos de Unidades de Conservação, dentre esses, no art. 14, está o grupo das Unidades de Conservação de Uso Sustentável sendo que uma dessas categorias é a APA.

De acordo o art.15 instituído pela Lei no 9.985, de 18 de Julho de 2000:

A Área de Proteção Ambiental é uma área em geral extensa, com um certo grau de ocupação humana, dotada de atributos abióticos, 
estéticos ou culturais especialmente importantes para a qualidade de vida e o bem-estar das populações humanas, e tem como objetivos básicos proteger a diversidade biológica, disciplinar o processo de ocupação e assegurar a sustentabilidade do uso dos recursos naturais.

Dando continuidade a definição de APA, Brasil, 1998 apud Cabral e Souza (2002, p.12):

As Áreas de Proteção Ambiental são unidades de conservação inseridas no grupo de uso sustentável destinadas a proteger e conservar à qualidade ambiental e os sistemas naturais nelas existentes, visando à melhoria da qualidade de vida da população local e também à proteção dos ecossistemas regionais.

É possível observar que áreas ambientalmente protegidas são necessárias em todo o mundo para preservação dos ambientes naturais, pois através delas será delimitada a exploração do solo e dos recursos naturais para melhor qualidade de vida do homem. Proteger a natureza é um dever que toda a sociedade mundial precisa cumprir, a fim de que a população atual possa usufruir sustentavelmente, dando oportunidades para as gerações futuras vivenciarem essa tão encantada natureza e poderem levar uma vida de qualidade e bem-estar.

Em relação à atuação do turismo em áreas protegidas, é preciso saber administrar bem essa questão, pois, esse segmento deve acontecer em consonância com a Legislação Ambiental. Os responsáveis pela administração e fiscalização da APA deverão monitorar todo o comportamento dos moradores para uso adequado dos recursos naturais incentivando-os ao procedimento de conservação.

As APAs podem conter propriedades públicas ou privadas, o que pode ocasionar dificuldades na gestão. Os ocupantes da APA deverão ter conscientização sobre o uso adequado do território protegido. Muitas vezes a falta de fiscalização e a má utilização das áreas protegidas pode levá-las a degradação. Segundo Pádua (2001, p. 425) sobre APA:

Dizer sobre uma categoria de unidade de conservação, como as Áreas de Proteção Ambiental (APAs), relativamente recente, criada no início da década de 1980, com características muito especiais, pois suas terras, na maioria dos casos, pertence a particulares, e que possui a maior extensão de terras, dentre todas as 
estabelecidas no Brasil, é um desafio, pois pode trazer algumas vantagens e muitas desvantagens que merecem reflexão.

A atividade turística sustentável poderá favorecer uma área de proteção que esteja sendo degradada através da política de educação ambiental com proprietários, comunidade, turistas, enfim, procurar através da educação ambiental, buscar a capacidade que cada indivíduo tem de adquirir uma conscientização sobre a sustentabilidade dos recursos naturais.

De acordo a definição da OMT (2003, p. 24):

O desenvolvimento do turismo sustentável atende às necessidades dos turistas de hoje e das regiões receptoras, ao mesmo tempo em que protege e amplia as oportunidades para o futuro. $\grave{E}$ visto como um condutor ao gerenciamento de todos os recursos, de tal forma que as necessidades econômicas, sociais e estéticas possam ser satisfeitas sem desprezar a manutenção da integridade cultural, dos processos ecológicos essenciais, da diversidade biológica e dos sistemas que garantem a vida.

A busca pela sustentabilidade nos dias atuais é a fonte essencial para a sobrevivência da humanidade e quando se refere ao desenvolvimento do turismo, há muito que se pensar, estudar e refletir. O turismo é etnocêntrico, ele está direcionado há vários setores da economia do país, gerando emprego para a população, causa satisfação às pessoas, pois ele dispõe de um exuberante conjunto de atrativos que causam bem-estar ao ser humano. O turismo, considerado uma indústria que se desenvolve a cada instante no mundo, é um bem sócio-econômico que deve ser usufruído através da sustentabilidade, pois, é determinado como um setor que causa muitos impactos ao meio em que atua. Esses impactos podem ser positivos e negativos, mas é importante salientar que os impactos positivos devem superar os negativos e por isso o termo sustentabilidade que está em evidência em todo o mundo poderá ser uma forma de reflexão a todos que usufruem dessa atividade tão rica e merecedora do desenvolvimento sustentável.

De acordo Rose (2002, p. 51) sobre turismo sustentável:

Está intimamente ligado à conservação dos recursos naturais ambientais que pode garantir a exploração sem deteriorar os recursos naturais, renovando-os, ao mesmo tempo em que vão 
sendo utilizados; satisfazendo a necessidade do momento, sem comprometer a capacidade para atender futuras gerações.

Para desenvolver o turismo sustentável numa área de proteção ambiental é necessário que se planeje um tipo de turismo mais cauteloso, como o ecoturismo que proporciona ao visitante um contato direto com a natureza, visando a preservação do ambiente natural. Ceballos - Lascuráin, 1993 apud Seabra, (2001, p. 30-31):

O turismo ecológico compreende uma viagem ambientalmente responsável, com visitação de áreas naturais relativamente preservadas, no sentido de vivenciar e apreciar a natureza, que promove a conservação, tem baixo impacto e promove, de forma benéfica, o envolvimento socioeconômico ativo das populações locais.

Para Bezerra (2003, p.66) ecoturismo se define como:

O ecoturismo é o segmento da atividade que utiliza, de forma sustentável, o patrimônio natural e cultural, incentiva a sua conservação e busca a formação de uma consciência ambientalista através da interpretação do meio ambiente, promovendo o bem-estar das populações envolvidas.

A segmentação pelo turismo ecológico, se bem planejado, poderá facilitar a sustentabilidade e preservar os recursos naturais disponíveis de uma APA devendo, para tanto, contar com a participação da comunidade na conciliação de exploração e conservação da natureza através da informação e participação, princípios basilares da educação ambiental. É importante destacar que num local de proteção ambiental o fluxo de turistas deve estar em consonância com a capacidade de carga do destino, pois um fluxo excessivo de turistas causa a degradação do ambiente, podendo levar a localidade ao declínio. Por isso é importante avaliar a capacidade de suporte do local ao elaborar o plano de desenvolvimento turístico.

Segundo a OMT (2003, p. 147) sobre capacidade de carga:

A análise da capacidade de carga é uma técnica básica que vem sendo amplamente aplicada no planejamento turístico e recreativo (e também no gerenciamento da vida selvagem), para auxiliar na conquista do desenvolvimento sustentável através de uma 
determinação sistemática dos limites máximos de desenvolvimento e de utilização dos visitantes, bem como do aproveitamento dos recursos turísticos.

Para que o turismo se desenvolva sustentavelmente numa Área de Proteção Ambiental, como já foi dito anteriormente e vale ressaltar mais uma vez, a atuação do planejamento é uma forte conduta de desenvolvimento, pois através dele será possível obter resultados elevados de sucesso e sustentabilidade dos ambientes natural, histórico e cultural.

\subsection{A Importância do Planejamento para a Atividade Turística}

É importante perceber o quanto é necessário o planejamento na atuação do turismo. Será através do planejamento que os passos seguirão corretos a fim de minimizar os danos e preservar a região de visitação turística. Munoz, 1999 apud Ignarra (2001, p. 62), apresenta um conceito de planejamento que aborda essas questões:

O planejamento consiste na definição dos objetivos, na ordenação dos recursos materiais e humanos, na determinação dos métodos e formas de organização, no estabelecimento das medidas de tempo, quantidade e qualidade, na localização espacial das atividades e outras especificações necessárias para canalizar racionalmente a conduta de uma pessoa ou grupo.

Planejar o turismo de uma localidade é extremamente importante, pois esse dará ao destino melhores condições de desenvolvimento da atividade, sem o planejamento, maiores problemas surgirão e conseqüentemente serão mais difíceis de resolvê-los.

Observa-se, portanto que o turismo e planejamento devem andar juntos sempre. Muitos problemas ocorrem e quando não há uma preparação para resolvêlos, além de ocasionar maiores complicações, todo o investimento aplicado em decorrência do desenvolvimento turístico poderá não ter resultados desejados. O plano de desenvolvimento precisa estar engajado nos campos econômico, social, cultural e ambiental para obter sucesso no processo de aplicação. 
No campo Econômico: um dos maiores problemas que interferem no desenvolvimento do turismo é a sazonalidade, devido às mudanças climáticas, férias e feriados que influenciam o meio turístico. Para suprir esta deficiência, é preciso ter uma boa infra-estrutura. Se não houver planos para lidar com acontecimentos inesperados, obviamente vai resultar insatisfação aos turistas e prejuízo para as atividades do turismo, pois qualquer empreendimento que não esteja organizado adequadamente à recepção de seus clientes tornar-se-á como um local fracassado. Porém, quando tudo é bem planejado, as chances de alcançar demanda e sucesso é bem maior, além de atingir as expectativas dos turistas. A comunidade local que sobrevive da economia do turismo também precisa estar atenta a essa questão do aparecimento de situações indesejadas, para que assim saiba resolvê-las.

Turismo gera emprego: O turismo dispõe de áreas diversificadas para a empregabilidade no setor. Através da sazonalidade ocorrente, a alta temporada é a época em que mais gera emprego, ocorrendo assim mudanças até nos setores de quem já trabalha diretamente com o turismo. São criadas novas oportunidades de trabalho e renda, além de aumentar as expectativas das pessoas que sobrevivem das atividades turísticas. Esse é um aspecto muito positivo no turismo, que deve ser levado em consideração o desenvolvimento e conhecimento da localidade, dentre os destinos turísticos.

De acordo a influência do turismo na economia, Bezerra (2003, p. 6) define:

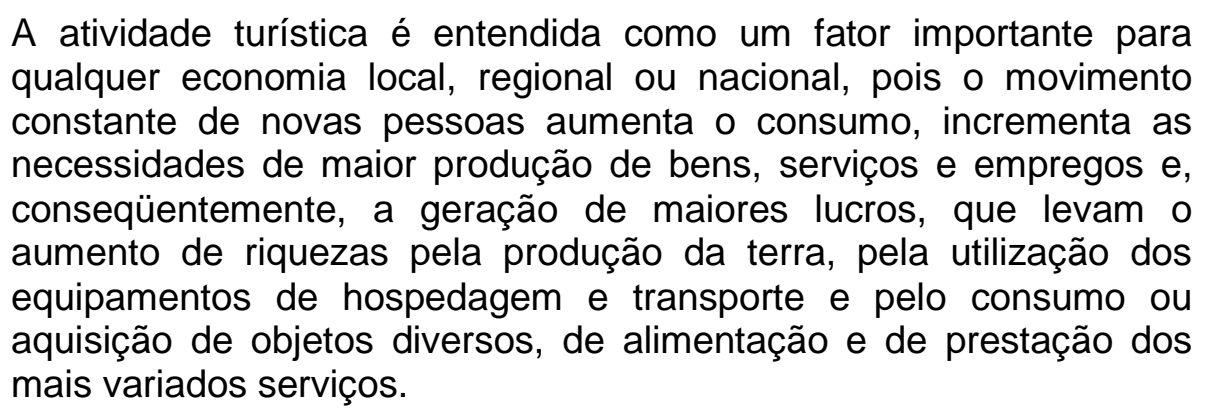

A atividade turística é entendida como um fator importante para qualquer economia local, regional ou nacional, pois o movimento constante de novas pessoas aumenta o consumo, incrementa as necessidades de maior produção de bens, serviços e empregos e, conseqüentemente, a geração de maiores lucros, que levam o aumento de riquezas pela produção da terra, pela utilização dos equipamentos de hospedagem e transporte e pelo consumo ou mais variados serviços.

No campo Social: A chegada de turistas a uma localidade pode interferir no convívio com a comunidade. Pois estes possuem culturas, crenças, costumes diferentes, além de aparentar alto poder aquisitivo, por portarem máquinas fotográficas, câmeras de vídeo, automóvel próprio ou alugado, estilo de vestir diferente, enfim, fazem com que a comunidade local tire conclusões não existentes, 
associando assim, a vida do turista com a sua realidade cotidiana e ocasionando, de certa forma, uma barreira social entre turistas e comunidade. Goeldner et al. (2002, p. 218) contextualiza sobre esse assunto:

A presença de visitantes em um país afeta os padrões de vida das pessoas nativas. A forma como os visitantes se portam e seus relacionamentos pessoais com cidadãos do país anfitrião costumas ter um efeito profundo sobre o modo de vida e as atitudes das pessoas locais.

Em relação à infra-estrutura, a sobre-exploração dos serviços ambientais - em especial, a água - pode levar à saturação pelo uso dos visitantes, causando problemas sérios nas instalações, fazendo assim com que os moradores locais impliquem com os turistas.

O número excessivo de turista pode ocasionar outros problemas relacionados à conduta moral da comunidade, como a prática do turismo sexual, abuso do trabalho infantil, excesso de barulho e alcoolismo, dentre outros. Todas essas situações desagradáveis, que ocorrem pelo mau desenvolvimento do turismo, precisam ser abordadas e minimizadas para que os moradores locais não se sintam tão invadidos e revoltados com a freqüência dos visitantes.

Quando uma localidade recebe muitos turistas, está sujeita a vários riscos, dentre os quais podem se destacar a especulação imobiliária, deslocamento de moradores para a periferia de outras cidades, graves doenças como a AIDS, cólera e malária que acabam sendo transmitidas pelos turistas aos residentes através do convívio. Essa é uma questão muito séria, em que medidas precisam ser adotadas previamente através de palestras sobre prevenção, cuidados ao relacionar-se com pessoas diferentes, cabendo aos responsáveis pelo desenvolvimento turístico local a adoção destas ações.

No campo Cultural: O turismo pode influenciar muito na cultura traduzida pelos costumes e hábitos da comunidade local, como também na cultura referente às artes e danças. Isso acontece em decorrência do grande número de turistas que chegam ao destino trazendo em sua bagagem culturas diferentes, meios de relacionamentos diferentes, fazendo com que as tradições e manifestações culturais 
da comunidade local tomem um outro rumo perdendo sua identidade cultural. Segundo Moura, 2001 apud Dias, (2003, p. 32):

muitas festas religiosas tiveram alteradas suas datas para permitir maior afluência do público, como no caso da Festa do Divino realizada em Diamantina e Serra em MG, que foi transferida para Julho, período de férias.

De acordo com Moura, é evidente a ocorrência de mudanças nos hábitos e costumes de uma comunidade devido ao turismo. Esse é um ponto que precisa ser diagnosticado para saber minimizá-lo.

No campo Ambiental: $O$ ambiente natural é uma das áreas do turismo que requer maior atenção e cuidado. Por sofrer muitos impactos, os atributos naturais podem ser prejudicados através do mau uso e assim ocorrer danos irreparáveis suportados não somente pelo meio natural, mas também pela comunidade e as gerações futuras.

Os impactos que o turismo causa, necessitam de um bom planejamento e monitoramento para eliminá-los, ou até mesmo fazer com que não ocorram. Se o turismo local for planejado e estruturado corretamente, será mais favorável tanto para a preservação das atividades naturais e culturais, como para a melhor qualidade de vida da comunidade local e maior desenvolvimento do turismo sustentável.

Neste contexto, o plano de manejo da APA de Santo Antônio, objeto deste estudo foi elaborado em 1999, pela Secretaria da Cultura e Turismo da BahiaSUDETUR com recursos do PRODETUR - Programa de Desenvolvimento Turístico da Bahia.

Segundo SUDETUR (1999, p. 5):

Com a criação dessa APA, objetiva-se assegurar o disciplinamento do uso do solo e sua ocupação, bem como a adequada proteção dos recursos naturais de uma área de $230 \mathrm{~km}^{2}$, que se estende limítrofe ao mar, da desembocadura do rio João de Tiba até próximo a Foz do rio Jequitinhonha. Abrangendo relevantes ecossistemas litorâneos remanescentes da Mata Atlântica, manguezais, várzeas associadas a restingas costeiras, falésias fósseis, praias e recifes de coral. 
De acordo com essa citação, nota-se que através dos critérios definidos no Plano de Manejo as medidas corretas para ocupação do território e plano de gestão, tornam-se imprescindíveis para a proteção e conservação da região.

O zoneamento da APA de Santo Antônio, de acordo com seu plano de manejo, foi definido em três categorias e dentro delas foram definidas as seguintes zonas, SUDETUR (1999, p. 26) :

* Categoria de Preservação

- ZPVS - Zonas de Preservação da Vida Silvestre;

- ZPR-E - Zona de Proteção Rigorosa Especial;

- ZPR - Zona de Proteção Rigorosa.

* Categoria de Conservação

- ZME - Zona de Manejo Especial;

- ZIR - Zona de Intervenção Restrita;

- ZOM - Zona da Orla Marítima.

\section{* Categoria de Uso Sustentável}

- ZAP - Zona de Agropecuária;

- ZOR - Zona de Ocupação Rarefeita;

- ZOR-E - Zona de Ocupação Rarefeita Especial;

- ZER - Zona de Expansão Urbana Rarefeita;

- ZEU - Zona de Expansão Urbana Prioritária;

- ZUP - Zona de Urbanização Prioritária;

- ZAE - Zona de Atividades Econômicas Diversificadas;

- ZEU-E1 - Zona de Expansão Urbana Especial 1; 
- ZEU-E2 - Zona de Expansão Urbana Especial 2;

- ZEU-E1 - Zona de Expansão Urbana Especial 3;

- ZAT - Zona de Apoio Turístico.

É possível notar que através deste zoneamento, a preservação, a conservação e o uso sustentável dos recursos da APA precisam ser respeitados e utilizados adequadamente. As Zonas especificadas em cada categoria do zoneamento definem a sua participação em combate a degradação do meio natural e a sua importância dentro de cada espaço da APA. Para um melhor entendimento sobre o zoneamento ecológico desta APA será possível a visualização do mapa no (anexo B).

Os objetivos do Plano de Manejo são indispensáveis para uma gestão tecnicamente correta, o que influi num futuro resultado positivo de conservação da APA e desenvolvimento da região. $O$ ecoturismo é a fonte de crescimento da região que apresenta ricas características, dispondo de atrativos naturais para o uso sustentável.

\subsubsection{Planejar é preciso}

Devido aos impactos causados pelo turismo, é imprescindível o monitoramento permanente de planejadores às atividades turísticas. A ação de um bom planejamento proporciona o crescimento sustentável do turismo e diminui em abundância os impactos negativos.

O planejamento é muito importante e disponibiliza mudanças e resultados, mas, além de bem elaborado, precisa ser dinâmico e aceitar modificações quando necessário e revisado periodicamente, pois, a cada momento surgem novas realidades e é importante o turismo atuar de acordo as mesmas.

Em relação ao monitoramento da atividade turística a OMT (2003, p. 104) diz que: 
Hoje em dia, a técnica utilizada para o monitoramento dos impactos é aquela que se estabelece os indicadores ambientais para cada área turística ou local de desenvolvimento. Esses indicadores são medidos periodicamente, e, no caso do surgimento de problemas, é possível adotar ações corretivas. A qualidade do produto turístico precisa ser mantida e este deve ser periodicamente revitalizado para que os níveis de satisfação dos turistas permaneçam altos e os mercados turísticos sejam preservados. Ao final de um processo, pode ser interessante para algumas áreas modificar 0 produto turístico e reorientar os mercados.

O planejamento da atividade turística exige a participação de todos os órgãos relacionados a este setor. É também muito importante a participação direta e indireta da comunidade, dos órgãos públicos e privados, Organizações não Governamentais, enfim, de todos aqueles que podem contribuir para melhor desempenho da atividade no âmbito cultural, social, econômico e ambiental.

Para desenvolver o turismo em determinada região, o planejamento deve estar relacionado com os planos de desenvolvimento dos órgãos Estadual e Municipal para que se encaixem e completem entre si.

Cabral e Souza (2002, p. 54) diz que "o poder público é o principal agente de gestão do meio ambiente como controlador", e ainda cita Castro et al. (1999) , "a sociedade se apresenta como alvo das ações de defesa do meio ambiente, cuja participação no processo é fundamental".

Os empresários envolvidos com a atividade, os órgãos públicos e privados, precisam ter uma participação ativa no desenvolvimento da política do turismo. Pois, a comunidade em geral é que deve saber quais os benefícios importantes que o turismo vai lhe proporcionar.

$\mathrm{O}$ ato de planejar significa a base para o desenvolvimento da atividade turística. Quando se fala em planejamento deve-se ter certeza da abrangência de metas a serem seguidas, pois para cada área que envolva o turismo há um planejamento, e esse deve ser bem elaborado.

A OMT (2003, p. 41) destaca:

Planejar é organizar o futuro de forma a atingir certos objetivos. $O$ planejamento oferece um guia para tomada de decisões por ações futuras oportunas. O planejamento no turismo tem por objetivo levar 
determinados benefícios socioeconômicos para a sociedade, sem deixar de manter a sustentabilidade do setor turístico.

Destacando o desenvolvimento do turismo local, o planejador poderá usar cada plano em sua área específica.

No aspecto social trabalhar proporcionando conhecimentos à comunidade local sobre o que é o turismo, o que ele proporciona e como deve acontecer. Essa deve trabalhar juntamente na aplicação dos planos para que possa ocorrer no futuro uma forte ligação entre turismo e comunidade receptora.

Na mesma proporção deve ser aplicado o planejamento dos atrativos culturais, preservando o artesanato, os costumes tradicionais, a culinária, o estilo de vida, onde possam ser usufruídos adequadamente para não interferir ou proporcionar mudanças no meio cultural da comunidade. Nas localidades onde o turismo está se desenvolvendo, sem nenhum planejamento, está ocorrendo uma invasão na cultura local e conseqüentemente essa vai sendo influenciada pelos turistas e de certa forma vai mudando a sua tradição.

É necessário mostrar aos turistas a importância da cultura local. Este é um trabalho muito sério em que a comunidade precisa estar unida, ao valorizar a cultura local, estará se incentivando a preservação dos atrativos culturais, e o turismo tem uma grande influência sobre esse aspecto.

Um importante tipo de planejamento a ser implementado está relacionado aos atrativos naturais e históricos. Ainda segundo a OMT (2003: p. 74): "São os atrativos turísticos os responsáveis por atraírem mais turistas a visitarem o local".

Diante desta visão, os objetivos do planejamento devem estar voltados para a melhoria de infra-estrutura, conservação dos atrativos naturais e preservação do patrimônio histórico. 


\section{3- METODOLOGIA}

A metodologia é muito importante para que uma pesquisa científica alcance seus objetivos, pois através dela foram colhidos os dados necessários para obtenção dos resultados. Somente com o processo metodológico o trabalho obteve um prosseguimento lógico e positivo para sua definitiva realização.

Em relação à definição de método de acordo Marconi; Lakatos (2000, p.44):

Todas as ciências caracterizam-se pela utilização de métodos científicos; em contrapartida, nem todos os ramos de estudo que empregam esses métodos são ciências. Dessas afirmações, podemos concluir que a utilização de métodos científicos não é da alçada exclusiva da ciência, mas não há ciência sem o emprego de métodos científicos.

\subsection{Tipo de Pesquisa}

O trabalho busca dar continuidade ao TCC - Trabalho de Conclusão de Curso, realizado em 2005 por essa pesquisadora, que consistiu de uma pesquisa descritiva visando inventariar os atrativos turísticos do povoado Santo Antônio e o interesse da comunidade no aproveitamento turístico destes atrativos. A proposta, agora, é incentivar o desempenho da atividade turística dentro da APA de Santo Antônio, utilizando os recursos disponíveis, buscando através de mais estudos e pesquisas, valorizar e divulgar a localidade. Sendo assim, foi utilizado o estudo descritivo sobre o povoado, no intuito de analisar e quantificar os dados adquiridos.

Na definição de Gil (2002, p.42):

As pesquisas descritivas têm como objetivo primordial a descrição das características de determinada população ou fenômeno ou, então, o estabelecimento de relações entre variáveis. São inúmeros os estudos que podem ser classificados sob este título e uma de suas características mais significativas está na utilização de técnicas 
padronizadas de coleta de dados, tais como o questionário e a observação sistemática.

De acordo Denker (2001, p. 130):

As pesquisas descritivas compreendem uma série de técnicas de levantamentos de dados como questionário, revista estruturada, entrevista semi-estruturada, pesquisa por telefone, pesquisa interativa, questionários enviados pelo correio, observação.

O método quantitativo foi um outro segmento seguido para a contribuição desse trabalho científico, pois esse método foi utilizado na pesquisa do TCC em 2005. Nesse estudo ele foi utilizado para orientação dos caminhos a serem percorridos por essa pesquisadora, no intuito de solucionar os problemas em questão da pesquisa em realização.

Para exemplificar melhor o método quantitativo, Oliveira (2000, p. 68) destaca:

Retomando os conceitos de método e técnica de pesquisa, pode-se afirmar que método científico é a definição das técnicas e caminhos a serem percorridos por uma pesquisa. São os recursos e procedimentos a serem utilizados pelos pesquisador na busca de solução para o problema. (...) O método quantitativo na pesquisa científica está sempre associado à experimentação e manipulação de um objeto estudado em uma população ou universo.

Além dos métodos descritivo e quantitativo usados na pesquisa anterior em 2005, foi possível a realização de outros métodos para esse estudo que trata da atuação da atividade turística em APA. A pesquisa Exploratória foi muito significante e favorável para esse trabalho, pois através dela foi possível à realização de entrevistas a pessoas interagidas com o tema em discussão, o que pôde dar maior qualidade e enriquecimento nesse estudo.

Segundo Gil (2002, p.41) pesquisas exploratórias:

(...) tem como objetivo proporcionar maior familiaridade com 0 problema, com vistas a torna-lo mais explícito ou a construir hipóteses. Pode-se dizer que estas pesquisas têm como objetivo principal o aprimoramento de idéias ou descoberta de intuições. Seu 
planejamento é, portanto, bastante flexível, de modo que possibilite a consideração dos mais variados aspectos relativos ao fato estudado.

Para Denker (2001, p.124):

\begin{abstract}
A pesquisa exploratória procura aprimorar idéias ou descobrir intuições. Caracteriza-se por possuir um planejamento flexível envolvendo em geral levantamento bibliográfico, entrevistas com pessoas experientes e análise de exemplos similares. As formas mais comuns de apresentação das pesquisas exploratórias são a pesquisa bibliográfica e o estudo de caso.
\end{abstract}

A pesquisa explicativa também foi usada nesse trabalho, pois a mesma tornouse continuação da pesquisa descritiva realizada anteriormente a essa, é o que afirma Gil (2002). Foi interessante utilizar essa pesquisa porque a mesma auxiliou de forma precisa aos resultados observados na pesquisa descritiva anterior.

Conforme Gil (2002, p.42):

Pode-se dizer que o conhecimento científico está assentado nos resultados oferecidos pelos estudos explicativos. Isso não significa, porém, que as pesquisas exploratórias e descritivas tenham menos valor, porque quase sempre constituem etapa prévia indispensável para que se possa obter explicações científicas.

Já a autora Dencker (200, p. 125) define da seguinte forma:

A pesquisa explicativa procura identificar os fatores que determinam
ou contribuem para a ocorrência dos fenômenos. Caracteriza-se pela
utilização do método experimental (na ciências físicas) e
observacional (nas ciências sociais). As formas mais comuns de
apresentação a pesquisa experimental e a pesquisa ex-post-facto.

A pesquisa bibliográfica ajudou muito através de teorias com assuntos relacionados ao tema abordado. As leituras feitas em livros, artigos, textos e outras publicações sobre o tema em questão foram fundamentais para concretização desse trabalho. 
A pesquisa bibliográfica de acordo Gil (2002, p. 44):

É desenvolvida com base em material já elaborado, constituído principalmente de livros e artigos científicos. Embora em quase todos os estudos seja exigido algum tipo de trabalho dessa natureza, há pesquisas desenvolvidas exclusivamente a partir de fontes bibliográficas. As pesquisas sobre ideologias, bem como aquelas que se propõem à análise das diversas posições acerca de um problema, também costumam ser desenvolvidas quase que exclusivamente mediante fontes bibliográficas.

Segundo Dencker (2002, p.125):

Desenvolvida a partir de material já elaborado: livros e artigos científicos. Embora existam pesquisas apenas bibliográficas, toda pesquisa requer uma fase preliminar de levantamento e revisão da literatura existente para elaboração conceitual e definição dos marcos teóricos.

Utilizou-se também o método documental, o qual pôde demonstrar, identificar e registrar melhor, através de fotografias, o local onde se realizou a pesquisa científica.

Gil (2001, p. 46) destaca muito bem essa questão:

O desenvolvimento da pesquisa documental segue os mesmos passos da pesquisa bibliográfica. Apenas cabe considerar que, enquanto na pesquisa bibliográfica as fontes constituídas sobretudo por material impresso localizado nas bibliotecas, na pesquisa documental, as fontes são muito mais diversificadas e dispersas. (...). Nesta categoria estão os documentos conservados em arquivos de órgão públicos e instituições privadas, tais como associações científicas, igrejas, sindicatos, partidos políticos, etc. Incluem-se aqui inúmeros outros documentos como cartas pessoais, diários, fotografias, gravações, memorandos, regulamentos, ofícios, boletins, etc. 
Segundo Dencker (2001, p.125), a pesquisa documental:

Difere da pesquisa bibliográfica por utilizar material que ainda não recebeu tratamento analítico ou que pode ser reelaborado. As fontes documentais podem ser documentos de primeira mão conservados em arquivos de instituições públicas e privadas (formulários da Embratur, registro de hóspedes) ou pessoais (diários, relatos de viagem). Além desses, temos os documentos de segunda mão: relatórios (de pesquisa, de empresas) e dados estatísticos (IBGE).

\subsection{População e Amostra}

O povoado Santo Antônio possui aproximadamente 1.820 habitantes, encontra-se numa região rica em atrativos naturais que devem ser explorados e preservados de acordo com a Legislação Ambiental, pois estão inseridos dentro de uma Unidade de Conservação que é a APA de Santo Antônio, criada pelo Decreto Estadual no 3.143, de 31 de agosto de 1994. A APA de Santo Antônio foi identificada pelo Plano de Manejo como uma área rica em atrativos ecoturísticos, os quais ainda não foram explorados.

$\mathrm{Na}$ pesquisa realizada em 2005 foram feitas entrevistas com o prefeito, a Secretária do turismo de Santa Cruz Cabrália, com três moradores antigos do povoado e com os índios da Aldeia Indígena Mata Medonha (O cacique e o Líder). Ainda foram aplicados questionários aos moradores do povoado.

Nessa pesquisa (2007) foram realizadas apenas duas entrevistas, uma com o secretário do meio ambiente de Santa Cruz Cabrália e outra com um morador voluntário que ajuda na preservação da APA de Santo Antônio.

\subsection{Instrumento de Coleta de Dados}

Utilizou-se, nesta pesquisa, dados secundários e primários. Os dados secundários demonstraram a existência dos atrativos bem como o potencial de utilização destes atrativos no desenvolvimento da atividade turística e a forma de utilizá-los. 
Os dados primários foram obtidos em entrevistas realizadas com o secretário do meio ambiente Sr. Euclides Senna e Sr. Antônio Barbosa Lacerda, voluntário morador de Santo Antônio, que ajuda na preservação da APA. Pôde-se utilizar as entrevistas anteriores realizadas em 2005 junto à secretária do turismo de Santa Cruz Cabrália, a Sra. Amale Abou Jokh e com o prefeito, o Sr. Ubaldino Alves Pinto.

Foram realizadas, ainda, entrevistas com moradores antigos da vila Santo Antônio, o Sr. Raimundo de Alcântara, a Sra. Valdenice Carlos da Silva e também os índios da Aldeia Indígena Mata Medonha, o cacique Sr. João Vitor de Oliveira conhecido como Maninho e o líder Sr. Israel Guedes de Souza, as quais não serão retratadas nesse trabalho.

Os resultados alcançados em 2005 pelos questionários que foram aplicados á população em geral, dão uma amostra aleatória simples da população, no intuito de verificar qual a opinião da mesma em relação ao desenvolvimento do turismo no povoado.

A amostra foi calculada com base na fórmula para cálculo de população finita descrita por Martins (2001), a qual estipulou-se um total de 65 questionários a uma população de 1.820 habitantes.

\subsection{Processo de Coleta de Dados}

O processo da coleta de dados consiste em relatar uma seqüência lógica da pesquisa como ocorreu nesse trabalho. As recentes entrevistas realizadas com o Sr. Secretário de Meio Ambiente, Sr. Euclides Senna, foi feita na própria Secretaria de Turismo e Meio Ambiente, numa segunda-feira, dia 29 de janeiro de 2007 entre 10:30 e 12:00 da manhã e com o Sr. Antônio Barbosa Lacerda, ocorreu em sua casa, numa terça-feira do dia 30 de janeiro de 2007 entre 09:00 e 10:00 da manhã. $\mathrm{Na}$ secretaria do turismo e meio ambiente, ainda foram colhidos alguns folders sobre a APA de Santo Antônio. Já as entrevistas realizadas em 2005, realizaram-se com o prefeito de Santa Cruz Cabrália, Sr. Ubaldino Alves Pinto em setembro de 2005 em sua residência no povoado Santo Antônio e com a Sra. Amale Abou Jokh em seu local de trabalho, na Secretaria do Turismo em julho de 2005. 


\subsection{Análise dos Dados}

A pesquisa objetiva estudo e análise dos resultados alcançados pelos métodos utilizados, visando propor a utilização sustentável dos atrativos turísticos encontrados na APA de Santo Antônio. Foram analisados quais os meios de se desenvolver um turismo sustentável dentro de uma APA, levando em consideração os dados colhidos através das entrevistas recentemente realizadas e também as entrevistas e questionários aplicados anteriormente, em 2005. Todo material coletado foi analisado sempre tendo em vista atingir o objetivo desse trabalho. 


\section{4- APRESENTAÇÃO E ANÁLISE dOS RESULTADOS}

\subsection{Anseios dos moradores e a realidade atual de Santo Antônio}

Através dos dados coletados (entrevistas, visitas ao local e uso da pesquisa realizada em 2005 por essa pesquisadora), constatou-se que a população de Santo Antônio está ansiosa para que a expansão do turismo ocorra na localidade. A esperança de uma melhor qualidade de vida e o desejo pelo progresso estão apostados na atividade turística, isso significa aos nativos que o turismo thes proporcionará uma melhor fonte de renda através da geração de empregos, onde novos horizontes de oportunidades surgirão.

De acordo com leituras bibliográficas sobre turismo, percebeu-se que esse setor tem sido de fundamental importância em pequenas localidades porque propicia o seu desenvolvimento. Uma localidade como Santo Antônio, pura e inocente desta atividade, possui uma grande vantagem, pois o seu crescimento poderá ser oferecido através de planos para manter a sua caracterização e preservação contínuas.

Santo Antônio é uma vila de pescadores de vida muito simples e pacata, carente de infra-estrutura para uma explosão turística, até mesmo porque está inserida numa APA e sua conservação é fundamental para manter os patrimônios natural e cultural defendidos do uso inadequado humano.

A população de Santo Antônio não possui uma necessidade de desenvolvimento turístico à toa, pois o povoado dispõe de uma beleza natural muito intensa que pode ser desfrutada da melhor maneira por visitantes e comunidade local.

Na ilustração 2 apresentada a seguir pode ser visualizada a vila Santo Antônio, retratando melhor a sua potencialidade natural para o sucesso da atividade turística. 


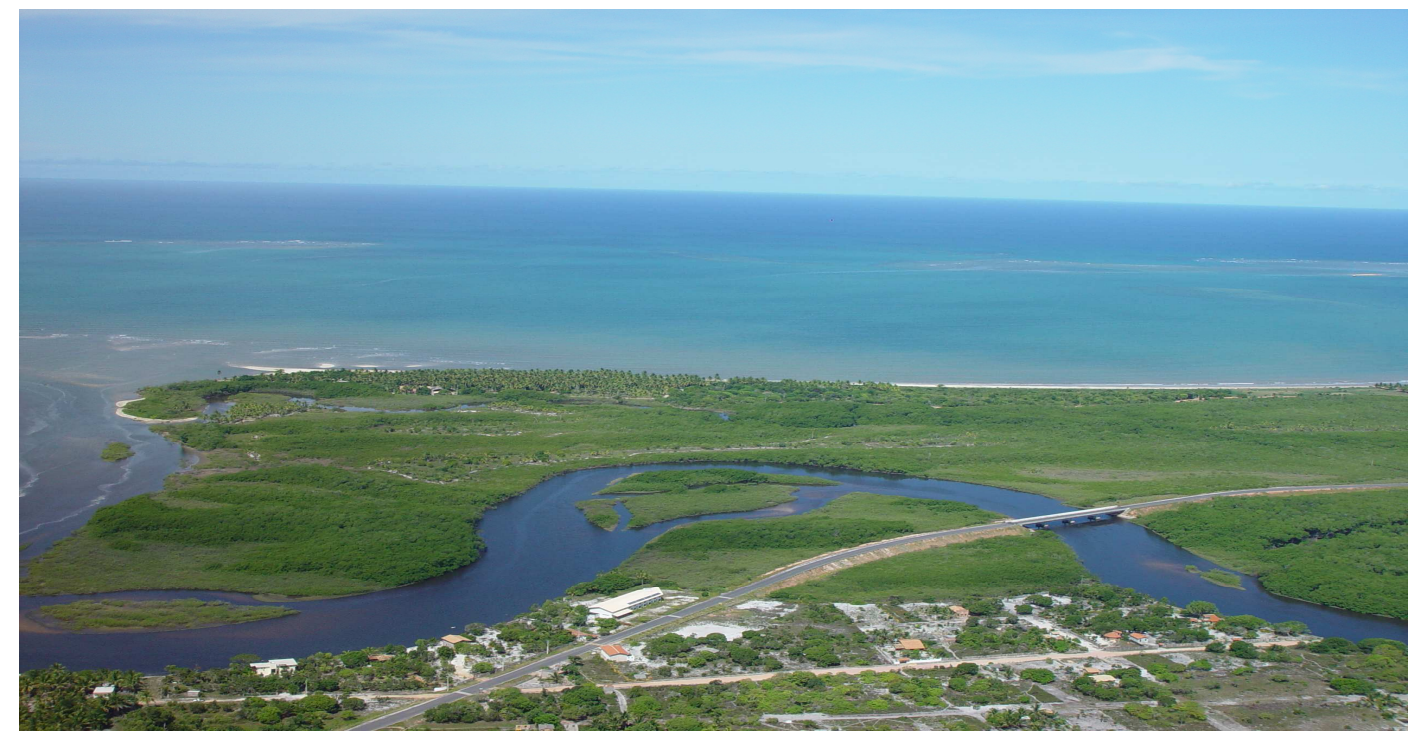

Foto vista aérea do povoado Santo Antônio

Fonte: Secretaria de Turismo de Santa Cruz Cabrália - Ba.

Essa foto está ilustrando o povoado Santo Antônio, o Rio Santo Antônio, a Praia de Santo Antônio e a ponte que separa os povoados Santo André e Santo Antônio.

Para chegar ao povoado é necessário fazer uma travessia de balsa com duração de 10 minutos pelo Rio João de Tiba, que antes era conhecido como Rio Sermambetiba. Esse rio banha parte do município de Santa Cruz Cabrália, propício para pescas e passeio de barcos. Ao atravessar o rio de balsa, logo chega ao povoado de Santo André, com mais $12 \mathrm{~km}$ de estrada encontra-se o povoado Santo Antônio.

\subsection{Aproveitamento dos recursos naturais para a possível atuação do turismo sustentável no destino}

Na continuidade da pesquisa sobre Santo Antônio, verificou-se que o Plano de Manejo da APA é de suma importância para a preservação da vida silvestre e dos recursos naturais disponíveis.

A atuação do turismo sustentável na APA de Santo Antônio deve ocorrer em conjunto com esse plano, considerando todas as características que visem a sustentabilidade da APA. 
São vários passos a seguir para a gestão ecoturística na APA de Santo Antônio. De acordo com o levantamento dos atrativos apontados pela comunidade, através da aplicação de questionários em 2005 por essa pesquisadora no povoado, obtiveram-se os seguintes resultados:

1. Praia de Santo Antônio;

2. Parque Ecológico - O Santuário;

3. Estátua de Santo Antônio;

4. Aldeia Indígena Mata Medonha;

5. Rio Santo Antônio;

6. Jangada - Ponto de Encontro dos Visitantes;

7. Mangue.

Ao analisar as categorias de Preservação, Conservação e de Uso Sustentável do Plano de Manejo da APA, verificou-se que os atrativos descritos acima poderão ser usufruídos de acordo com o que foi estabelecido no Plano de Manejo e aprovados para o uso sustentável pela administradora da APA.

Poderão ser utilizadas áreas que não prejudiquem a fauna e a flora. Na Zona de Apoio Turístico - ZAT, verificou-se que a atividade turística poderá se atuar próximo ao núcleo urbano, nas áreas de restinga fora das ZPR's - Zona de Proteção Rigorosa, na margem esquerda do Rio Santo Antônio.

Sendo assim, a melhor explanação de uso indicado das áreas será através do Plano de Manejo, o qual está descrito detalhadamente no (anexo B). Levando-se em consideração os dados obtidos a partir das entrevistas, é importante descrevê-los e adicioná-los no possível planejamento do turismo sustentável quando for elaborado, pois foram esses os atrativos escolhidos pela comunidade.

Cada atrativo deverá ser estudado separadamente, ter conhecimento sobre a capacidade de carga coerente para o local de visitação turística e qual o meio mais viável para trabalhar de forma respeitável com o manuseio do Plano de Manejo e o plano de desenvolvimento turístico. 
Nesse aspecto, será imprescindível que cada recurso natural usado para atração turística deverá ter sua estrutura adequada, compatível a uma nova prática sustentável influenciada pelo turismo.

Os atrativos turísticos de um destino são fundamentais para que a localidade obtenha demanda e sua conservação torna-se necessária para a apreciação do turista.

A utilização dos recursos disponíveis na APA será primordial para que a atividade turística aconteça na região, pois sem atrativo não há como desenvolver o turismo na localidade.

\subsection{A importância do turismo sustentável no povoado para o bem-estar da comunidade local}

Relacionar a importância do turismo no povoado com o uso sustentável da APA é essencial para o bem-estar da comunidade e para melhor especificar essa relação entre turismo sustentável em APA, foi possível através de entrevistas realizadas in loco fazer uma comparação entre a necessidade do desenvolvimento turístico em consonância com o Plano de Manejo. As entrevistas ocorreram com duas pessoas que trabalham na preservação da APA de Santo Antônio. A primeira entrevista ocorreu ao Sr. Euclides Senna, secretário do meio ambiente e ao Sr. Antônio Barbosa Lacerda, morador voluntário que ajuda na preservação da APA. Os dados observados obtiveram os seguintes resultados:

A entrevista realizada ao Sr. Euclides Senna (apêndice A) mostrou que a APA é importante para a preservação, conservação e sustentabilidade não só dos recursos naturais, mas principalmente para garantir a sobrevivência do homem.

Observou-se na entrevista que o Plano de Manejo está adequado ao desenvolvimento da APA, o entrevistado demonstrou com clareza saber da sua existência e importância para o crescimento sustentável local, mas o referido plano de manejo ainda não foi implementado efetivamente ficando só um estudo teórico sem aplicação prática. 
O Sr. Euclides acrescentou que a APA veio em boa hora, pois a região ao redor de Santo Antônio estava crescendo desordenadamente e a APA, como instrumento de ordenamento territorial, indica formas sustentáveis de crescimento. As idéias demonstradas na entrevista sobre o desenvolvimento turístico na região estão conciliáveis com os objetivos do Plano de Manejo, o que apresenta um ponto forte de incentivo a sustentabilidade da APA em relação à prática do ecoturismo.

O entrevistado falou que o Plano de Manejo foi feito de forma correta e disse que está seguindo o caminho com exatidão. Ele falou sobre o Plano Diretor Municipal e explicou que este ainda está sendo elaborado para ser implementado, começou a ser feito no dia 05 de janeiro de 2007, mas desde 2006 que foi determinado.

A preparação e execução do Plano Diretor facilitarão muito para que em consonância com o Plano de Manejo, o destino obtenha uma propagação viável e ecologicamente sustentável para garantia de uma melhor qualidade de vida local.

Ao estudar o Plano de Manejo da APA, certificou-se de que o mesmo foi publicado em setembro de 1999 pelo SUDETUR - Secretaria da Cultura e Turismo, o qual já estabeleceu o zoneamento da APA, definindo como cada zona especificada deverá ser preservada e usada.

O Plano de Manejo foi definido por meio de um Diagnóstico Ambiental através do clima da região, da geologia, da geomorfologia, dos solos, dos recursos hídricos, ecossistemas e dinâmica antrópica. Ainda por meio de um Zoneamento Ecológico Ambiental, do Balanço das Categorias de Zoneamento e dos Atrativos Ecoturísticos da Região.

Em entrevista ao morador voluntário da APA, o Sr. Antônio Barbosa Lacerda (apêndice B), falou sobre a preservação da APA, o quanto é importante a comunidade se unir para proteger o meio ambiente. Que não adianta querer só usufruir os recursos disponíveis porque quando esses acabarem de que forma 0 homem vai sobreviver? Isto demonstra que formadores de opinião dentro da população valorizam seu produto e querem utilizá-lo de forma sustentável.

O voluntário diz que eles trabalham na preservação da APA em cima do Plano de Manejo, juntamente com os órgãos IBAMA (Instituto Brasileiro do Meio Ambiente e dos Recursos Naturais), CRA (Centro de Recursos Ambientais) e Marinha. O Sr. 
Antônio afirmou que quando há desmatamento em alguma área, imediatamente eles solicitam a fiscalização do órgão responsável.

Ambos entrevistados trabalham na preservação do ambiente natural, visando buscar o uso sustentável da APA, sem prejuízo nem sobrecarga para os recursos naturais, procurando conservar o que lhes é de valor, no intuito de proporcionar as gerações futuras o usufruto desses recursos.

Pelo que pôde ser observado durante a visita local e as entrevistas realizadas, nem a APA, nem seu plano de manejo são do conhecimento geral, e sua aplicabilidade ainda não está no consenso local.

Houve uma concordância das entrevistas com o Plano de Manejo no sentido de proteção e conservação do patrimônio, o que poderá facilitar a implantação do ecoturismo dentro da APA.

Pelo que foi compreendido nas entrevistas, atentou-se que é necessário relacionar os projetos e objetivos do Plano de Manejo com os anseios da sociedade na busca de um crescimento sustentável através da prática do ecoturismo dentro da APA. E, pelo que foi observado na pesquisa há pretensão de se percorrer um caminho certo. Mas para que esse caminho seja concretizado corretamente é fundamental implantar o plano de manejo com a participação comunitária

\subsection{Esclarecimento da população através de educação ambiental sobre a importância de uma APA}

De acordo a pesquisa realizada com os moradores do povoado de Santo Antônio sobre o turismo (2005), observou-se nos resultados que a comunidade almeja o turismo na localidade, pois acredita que através da geração de emprego poderá obter uma vida melhor, sem precisar sair do local residente para outras localidades na busca pelo trabalho.

Mas, não basta apenas a comunidade querer que o turismo atue em sua região, ela deve estar ciente de muitas questões importantes. Primeiramente será preciso:

- comunicá-la sobre a existência da APA e sua função; 
- instruí-la através de aulas educacionais para que saiba trabalhar com o turismo dentro de uma APA;

- informá-la sobre o Plano de Manejo da APA e sua importância;

- esclarecê-la sobre a sustentabilidade do meio ambiente natural e cultural;

- ensiná-la como participar voluntariamente na preservação da APA, compondo seu Conselho Consultivo e auxiliando na implementação do o Plano de Manejo;

- realizar palestras nas escolas, no intuito de engajar os estudantes conscientemente na conservação da APA;

- criar associações de moradores e incentiva-las a monitorar a conservação da APA;

- instruí-la para a receptividade dos turistas;

- Implementar através de pedagogias especializadas um ensino educacional ambiental de acordo com a localidade e suas necessidades;

- Trabalhar sempre o resgate dos patrimônios natural e cultural da localidade.

Na verdade será necessária a realização de um trabalho com a comunidade mostrando a ela qual o seu papel enquanto moradores de uma destinação turística que se encontra dentro de uma Unidade de Conservação.

A educação ambiental é o ponto chave para aperfeiçoamento da qualidade de vida local, melhoramento dos problemas causados pelos impactos em uma área de preservação. Todavia, torná-la necessária e obrigatória nas escolas será uma experiência confiante e de caráter prático em busca de uma nova consciência ambiental.

É fundamental demonstrar para a comunidade que a educação ambiental é um importante catalisador do desenvolvimento local, capaz de instrumentar a população para um caminho coerente em busca de um relacionamento saudável e compatível 
com o meio ambiente, essa contextualização torna-se favorável a sustentabilidade da APA.

Ao tratar da comunidade e do Plano de Manejo da APA de Santo Antônio, é necessário levar em consideração algumas observações rumo a sustentabilidade:

- É preciso observar se o modo de vida da comunidade está de acordo com a legislação ambiental e se está usufruindo adequadamente dos recursos que lhes é proporcionado;

- Diagnosticar se o Plano de Manejo prevê alguma alteração no modo de vida da população local;

- Verificar se a população está de acordo com as mudanças que poderão ocorrer.

Essas questões destacadas acima poderão ser o começo de várias outras que surgirão no decorrer do desenvolvimento que irá acontecer na Vila Santo Antônio daqui mais um tempo, onde se espera um crescimento ecoturístico planejado e sustentável.

\subsection{Importância da inclusão da atividade turística no Plano de Manejo da APA para melhor desempenho do turismo dentro da APA de Santo Antônio}

$\mathrm{Na}$ intenção de propor um melhor desempenho da atividade turística dentro a APA de Santo Antônio, incentiva-se aqui a inclusão do turismo no Plano de Manejo da APA. Através dessa inclusão o trabalho de desenvolver um turismo sustentável será mais viável. As possibilidades de um turismo cauteloso serão mais significativas, tornando assim as chances de um crescimento local mais prováveis e seguras.

Para melhor entendimento dessa questão, será possível notar através das entrevistas realizadas anteriormente (2005) e as entrevistas acontecidas recentemente (2007) na região, que o Plano de Manejo não tem tido a exeqüibilidade desejada. 
Há exigências destacadas no próprio Plano de Manejo da APA (1999), que é imprescindível a participação das prefeituras da região, dos Órgãos Estaduais e Federais, além da Sociedade Civil, do órgão gestor da APA - CRA (Centro de Recursos Ambientais).

Em observação a entrevista realizada em (2005) com o prefeito de Cabrália, Sr. José Ubaldino (apêndice $\mathrm{C}$ ), notou-se que o órgão municipal está de apoio e concordância com as exigências do Plano de Manejo da APA.

Ainda nesta entrevista com Sr. Prefeito de Cabrália, ele afirmou que primeiramente deve-se buscar uma infra-estrutura de apoio turístico para o povoado e a partir daí procurar o desenvolvimento, potencializando a atividade turística na localidade.

Porém, há uma contradição nessa questão de infra-estrutura, pois o entrevistado tem planos para realização de uma grande festa no povoado Santo Antônio, onde o mesmo não possui infra-estrutura adequada para suportar uma grande massa de turismo.

Seria interessante e aconselhável que as autoridades estudassem melhor essa idéia e possa promover uma festa cultural mais simples, onde as comunidades local e do entorno possam usufruir melhor, e o meio ambiente menos prejudicado.

Pode-se ter como exemplo o turismo massificado de Porto Seguro, pois o destino tornou-se saturado devido a grande quantidade de turistas que freqüentam a localidade. A falta de planejamento e o turismo de massa podem levar o destino ao declínio, além de acabar com a tranqüilidade da comunidade residente. Por isso a importância de planejar antes da atuação turística nalocalidade.

A secretária do turismo de Cabrália Sra. Amale Abou Joh (2005) numa entrevista (apêndice D), diz que antes da expansão do turismo será necessário um projeto para o desenvolvimento do turismo de Santo Antônio e o primeiro passo a seguir seria um trabalho de conscientização com a população em relação ao turismo.

Nesse aspecto, observou-se que os entrevistados demonstraram interesse no desenvolvimento do turismo no povoado, mas acreditam que o jeito desse fenômeno acontecer está na elaboração de um plano gestor de desenvolvimento turístico, o 
que não deixa de ser uma realidade, que precisamente deve ser feita em consonância ao Plano de Manejo da APA.

A inclusão da atividade turística e dos planos de desenvolvimento local no Plano de Manejo facilitará a tão difícil sustentabilidade prevalecer na região, fazendo com que o turismo passe a ter um outro valor, além de só causador de impactos negativos a natureza. Se elaborado conforme as exigências o planejamento turístico, incluindo-o ao desempenho do Plano de Manejo, os impactos positivos do turismo poderão superar os impactos negativos e o povoado Santo Antônio, ficará como um exemplo a ser seguido por outras localidades com chances de se desenvolver sustentavelmente.

\subsection{Incentivar a preservação e conservação dos recursos naturais e da identidade cultural dos nativos}

Para alcançar os objetivos de se desenvolver um turismo sustentável em Santo Antônio, os incentivos econômicos, de infra estrutura bem como de capacitação de pessoal são primordiais, pois somente através destes mecanismos é que se concretizará, com sucesso, os objetivos propostos.

No decorrer de um crescimento turístico local, muitas coisas podem acontecer e existe algo de muito importante que ainda não foi esclarecido àquela humilde população de Santo Antônio, o que se define em uma preparação antes dessa expansão turística se concretizar.

É preciso explicar àquela população que a preservação do meio ambiente vem em primeiro lugar, que um plano de conservação dos recursos naturais e culturais deve ser elaborado e um trabalho de conscientização ambiental deve ser realizado com os moradores. O entendimento de que o produto turístico que gerará a renda possa se deteriorar pelo mau uso e que é fundamental logo no início do processo realizar um programa de incentivo a preservação.

Os moradores precisam ser esclarecidos que o local onde residem é propriedade deles e que não pode ser invadido por pessoas estranhas, capazes de tomar o seu espaço e coloca-los à margem do processo de desenvolvimento. 
Portanto, cuidados devem ser adotados para se alcançar fielmente os objetivos propostos. A garantia da preservação cultural é um alvo importante que deve ser esclarecido e incentivado à comunidade, prevenindo-a para uma possível descaracterização na identidade cultural local, causada por invasão de turistas em conseqüência da má utilização do espaço ecoturístico.

Os nativos devem estar cientes de que estão instalados dentro de uma APA, o que, se à primeira vista pode parecer um complicador, na realidade não o é, pois, por se tratar de unidade de conservação, há sempre mais e mais seguras fontes de financiamentos e de interesse. Neste contexto, toda mudança que ocorrer deve estar em consonância com o Plano de Manejo da APA, o que precisa ser explicado de forma recorrente a população sobre sua existência e importância.

Embora o povoado não esteja ainda indicado nos destinos turísticos da Bahia e do Brasil, é inegável que a região do entorno esteja se desenvolvendo o que pode trazer o turismo emergente, num local pobre de infra-estrutura, sem qualquer planejamento para a execução de tal atividade e, nesse caso, os valores ambientais, culturais e sociais podem se perder e o sonho de se tornar um destino de riqueza e progresso será imobilizado.

A conscientização e o incentivo são indispensáveis para a prática da preservação, conservação e uso adequado dos recursos naturais pela comunidade, mostrando que ao agir conscientemente, proporciona maior segurança na vida natural e cultural da região. 


\section{5- CONSIDERAÇÕES FINAIS}

A vila Santo Antônio pode ser considerada um paraíso tropical, já que possui uma beleza exuberante e de uma extensa área tão rica em recursos naturais, o que proporciona aos nativos uma vida tranqüila e de total comunhão com a natureza. Esse aspecto é fundamental para uma qualidade de vida saudável, o que poderá também ser proporcionada a uma possível camada de ecoturistas que preferem sair de sua rotina habitual em busca de um contato mais satisfatório com o meio ambiente.

Conclui-se que o estudo realizado sobre a atuação do turismo na APA de Santo Antônio pode se desenvolver sustentavelmente sim, porém, será uma tarefa complicada e árdua tendo em vista as dificuldades de acesso, inexistência de infraestrutura e falta de capacitação do pessoal local. Será necessária total dedicação de todos os responsáveis envolvidos (comunidade, órgãos públicos e privados) com a região.

No momento não há nenhuma evidência desse desenvolvimento turístico sustentável, mas se as coisas começarem a fluir com preparação, visando o melhor para o destino e bem-estar da população local, o desenvolvimento do turismo sustentável poderá acontecer.

Os caminhos a percorrer são muito difíceis de serem realizados, porém não são impossíveis. Se houver plena dedicação, precaução e principalmente respeito, o povoado poderá adquirir uma nova qualidade de progresso através do ecoturismo que se transformará no maior meio de sobrevivência local.

A partir do estudo em pauta, sugere-se a elaboração de um planejamento turístico sustentável em consonância com o Plano de Manejo da APA o qual deverá adotar, como ponto de partida, os seguintes procedimentos:

a. Fazer um diagnóstico da realidade sócio-ambiental atual do povoado;

b. Iniciar um planejamento junto à comunidade, mostrando que o mesmo deverá ser compatível com o Plano de Manejo da APA;

c. Aproveitar o Plano de Manejo para incentivar o uso sustentável dos atrativos adequando-os, se necessário, ao planejamento turístico; 
d. Diagnosticar as áreas de atuação do turismo e verificar se estão autorizadas para o uso sustentável de acordo o Plano de Manejo;

e. Incentivar através de campanhas educacionais toda a região do entorno a trabalhar com o turismo sustentável, mostrando que é melhor para a qualidade de vida da população e sobrevivência dos recursos naturais;

f. Passar informações aos visitantes sobre a existência da APA e a prática do ecoturismo;

g. Realizar freqüentemente a ação de educação ambiental aos moradores e visitantes;

h. Promover a divulgação da localidade de placas explicativas nas estradas que incentivem o uso sustentável dos atrativos, quando todo o plano de desenvolvimento estiver pronto para recepção de turistas;

Através da junção do planejamento do turismo com o Plano de Manejo, da participação de todos interessados no crescimento e na prática da atividade turística em busca da sustentabilidade local, o turismo poderá se desenvolver adequadamente e proporcionar a almejada melhoria da qualidade de vida da população local.

Se ocorrer o contrário, um turismo massificado e insustentável, será uma catástrofe, pois uma região de reserva ambiental tão rica em atrativos ecoturísticos poderá se decair por inconseqüência e irresponsabilidade humana. 


\section{REFERÊNCIAS BIBLIOGRAFICAS}

BARRETO, Margarida - Turismo e Legado Cultural. Campinas - São Paulo: Papirus, 3를. de 2002.

BEZERRA, Deise Maria Fernandes. Planejamento em Gestão e Turismo. São Paulo - SP: Roca, 2003.

CABRAL, Nájila Rejane Alencar Julião e SOUZA, Marcelo Pereira. Área de Proteção Ambiental: Planejamento e Gestão de Paisagens Protegidas. São Carlos - SP: Rima, 2002.

CONSTITUIÇÃO FEDERAL - SNUC - Sistema Nacional de Unidade de Conservação da Natureza. Lei oํ 9.985, de 18 de Julho de 2000.

DENKER, Ada de Freitas Maneti - Métodos e Pesquisa em Turismo. São PauloSP: Futura, 2001.

DIAS, Reinaldo. Planejamento do Turismo: Política e Desenvolvimento do Turismo no Brasil. São Paulo: Atlas, 2003.

GOELDNER, Cahrles; RITCHIE, Brent; McINTOSH, Robert - Turismo, Princípios, Práticas e Filosofias. Porto Alegre - RS: Boockman, 8 $8^{\mathrm{a}}$ ed. de 2002.

GIL, Antônio Carlos. Como Elaborar Projetos de Pesquisa. São Paulo - SP: Editora Atlas, 4⿳亠丷厂 edição, 2002.

IGNARRA, Luís Renato. Fundamentos do Turismo. São Paulo: Pioneira Thomson Learning, 2001. 2 reimpressão, da 1 ed. de 1998.

MARTINS, Gilberto de Andrade. Estatística Geral e Aplicada. São Paulo: Atlas, 2001.

OLIVEIRA, Claudionor dos Santos. Metodologia Científica, Planejamento e Técnicas de Pesquisa : Uma visão Holística do Conhecimento Humano. São Paulo: LTR, 2000.

OMT (Organização Mundial do Turismo) Guia de Desenvolvimento do Turismo Sustentável. Porto Alegre - RS: Boockman, 2003. 
OMT Organização Mundial do Turismo. Desenvolvimento de Turismo sustentável: Manual para organizadores locais, Embratur - Instituto Brasileiro de Turismo, 1995.

PÁDUA, Maria Tereza Jorge. Direito Ambiental das Áreas Protegidas, Rio de Janeiro - RJ: Frense Universitária , 2001.

ROCHA, Sheila Silvyane Silveira. TCC: Sugestões para o Desendolvimento Turístico de Santo Antônio - Santa Cruz Cabrália - Ba. FTC - Vitória da Conquista - Ba, 2005.

ROSE, Alexandre Turatti. Turismo: Planejamento e Marketing. Barueri - SP: Manole, $1^{\text {a }}$ ed. de 2001.

RUCHMANN, Doris - Turismo no Brasil, Análise e Tendência. Barueri - São Paulo: Manole, $1^{\underline{a}}$ ed. de 2002.

SEABRA, Giovanni. Ecos do Turismo: turismo Ecológico em áreas Protegidas. Campinas - SP: Papirus, 2001.

SUDETUR, Secretaria da Cultura e Turismo. Plano de Manejo: Área de Proteção Ambiental, Santo Antônio - Síntese. Pallotti, 1999. 


\section{APÊNDICES}




\section{APÊNDICE A}

\section{Entrevista realizada ao Secretário do Meio Ambiente, Sr. Euclides Senna, sobre a APA de Santo Antônio - Ba.}

No intuito de aproveitar os recursos naturais e incentivar o turismo sustentável dentro da APA de Santo Antônio, realizou-se uma entrevista ao Sr. Euclides Senna, secretário do meio ambiente de Santa Cruz Cabrália. A entrevista ocorreu na Secretaria de Meio Ambiente, numa segunda-feira, entre $10 \mathrm{~h} 30$ e $12 \mathrm{~h}$ do dia 29 de Janeiro de 2007.

Para elaborar a entrevista foram listados previamente uma seqüência de tópicos que possibilitaram a coleta dos dados necessários, porém, no decorrer da entrevista não necessariamente foi seguida uma seqüência dos tópicos.

- Sobre APA e sua importância;

- Sobre a APA de Santo Antônio;

- Turismo na Costa do Descobrimento e em Porto Seguro - Ba;

- Plano de Manejo da APA de Santo Antônio;

- Possibilidade de um planejamento Turístico do povoado;

- Existência da secretaria da APA de Santo Antônio;

- Sobre a organização das reuniões da APA;

- Possibilidade de um turismo sustentável no povoado;

- Importância do turismo para economia local;

- Educação ambiental aos nativos.

O Sr. Euclides Senna iniciou a entrevista sobre a APA, explicando o que é uma APA, qual a sua importância. Ele afirmou que APA é uma seleção do Estado, o qual cria um decreto, seleciona algumas áreas e as define como APAs. Dentro dessas APAs são definidas as zonas, como por exemplo zona de amortecimento, zona turística, zona mista, zona rarefeita, e assim segue a classificação das zonas. 
O secretário continua a sua explicação dizendo que a APA é como uma autoridade do Governo do Estado, é uma lei estadual, lei externa do município. Mas, antes que se defina uma APA, primeiro ouve-se a comunidade para saber a sua opinião sobre o assunto.

Cria-se uma APA para manter o local nativo, o morador antigo, respeitando as culturas, as tradições. Esse é o sentido de APA, pois trata-se de uma proteção ambiental para não desgastar o homem e a natureza, justamente para fixar 0 homem no lugar dele.

Embora tenha o plano de manejo, o Sr. Euclides afirma que os planos diretores municipais foram estipulados desde o ano de 2006, mas só agora é que eles estão sendo feitos, porém ainda não definiram onde deve ser construído dentro da APA. Esta APA já possui mais de 10 anos desde a sua criação. Somente este ano (2007), no dia 05 de janeiro é que foi criado o plano diretor do município de Cabrália. Esse plano diretor foi antecipado para definir áreas, onde os biólogos, os antropólogos, os geólogos, os historiadores, vieram e conheceram as áreas da APA, especificamente com características de migração de animais, fauna e flora exuberante que devia ser protegida, o crescimento da cidade, o comércio e o turismo, para diagnosticá-las e possivelmente intacta-las.

O secretário afirma que a região é de turismo. E se pergunta: O que quer dizer isso? Ele mesmo responde dizendo que nos locais de turismo podem ser construídos hotéis, restaurantes, boutiques e não um açougue, uma oficina ou marmoraria, pois não combina com atividade turística.

De acordo Sr. Euclides a APA é muito interessante, mas as pessoas precisam entender isso. Geralmente a APA vem de terras particulares. O Sr. Euclides exemplifica da seguinte forma: Se você possui uma fazenda de $2 / 3$ mil metros de frente para o mar, $100 \mathrm{~km}$ de fundo, e você imagina que o seu pedaço de terra de frente para o mar vai ser prejudicado por ser uma APA. Ele diz que não. O terreno será rebandeado, pois estará em função de uma lei federal que impõe isso. Áreas de preservação como o mangue, a restinga, a mata semiárida, são áreas que não podem ser construídas, o mangue por exemplo porque está numa área virgem.

Quando se pretende construir numa área particular, uma pousada, um hotel ecológico e não tem definido como deve ser construído, então o proprietário constrói 
como quiser. Mas existem pessoas que possuem uma postura conscientemente positiva em relação ao desenvolvimento local e consegue entender que naquele espaço, naquela área devem ser construídos apenas empreendimentos de usufruto turístico, pois está se tratando de uma zona turística. Se uma pessoa não tem vocação para a atividade turística, que venda, diz o secretário.

Segundo o entrevistado uma área turística deve conter estabelecimentos mistos, como hotel, restaurante, loja de conveniência, farmácia, empresa de guias de turismo, enfim, o que esteja realmente adequado ao local. Já a construção de casas pode ser ruim devido ao barulho causado pela movimentação de turistas.

O secretário segue a entrevista falando sobre a Costa do Descobrimento e destaca que é uma região em que o turismo está crescendo muito. É uma região que possui 3 APAs, duas em Cabrália a APA de Coroa Vermelha e a APA de Santo Antônio, a outra no município de Porto Seguro que é a APA de Caraíva e Trancoso.

Sr. Euclides já foi secretário do meio ambiente em Porto Seguro e hoje como secretário do meio ambiente de Cabrália, responsável também pela preservação da APA de Santo Antônio, da o seguinte depoimento: "como secretário do meio ambiente aqui, eu pensei que se não houvesse essa $A P A$, se não houvesse aprovado o plano diretor, eu pessoalmente teria ido lá para frear o crescimento desordenado. É o meu desejo e o mais importante de tudo isso, seja APA, seja plano diretor é que as pessoas precisam ver um ponto que Caetano Veloso diz naquela música (a força da grana que ergue e destrói coisas belas).Para ele o empregado ou empreendedor precisa ter uma visão de turista, uma visão empreendedora, caso contrário acaba construindo coisas ruins e feias, impactando o turismo no próprio plano dele. Ele quis dizer também que as coisas devem acontecer e desenvolver controladamente e não desordenadamente.

A APA serve para ordenar, organizar o desenvolvimento de localidades, de áreas de preservação, o Sr. Euclides diz que se ele não pode proibir pessoas que venham construir seus chalés, armazéns, curral, etc., já que ele não possui uma lei própria, ele não pode determinar nada. Mas, demonstra que com a APA e uma lei em mãos tudo funciona diferente, pois através dessa ele pode sim determinar. Por exemplo uma zona de vida silvestre, quer dizer que essa zona é refúgio de 
pássaros, ou lugar de acasalamento dos pássaros, portanto a vida silvestre é intensa e precisa ser preservada.

Sr. Euclides afirma que a APA faz as pessoas aprenderem na marra, de forma compulsória, impondo respeito a vida silvestre, a colônia de pescadores, aos locais de canoas e barcos, aos nativos, enfim, mostrando que dentro de sua área não se pode mudar de qualquer jeito. O entrevistado disse que nas proximidades do rio Santo Antônio existe um local onde barcos atracavam antigamente e lá ficavam, eram barcos de pescadores simples, nativos. Até que um dia chegou um hotel e fez área particular e hoje os barcos não mais podem aportar. Ele disse que é um pedacinho da história de Santo Antônio que estava indo embora e que hoje deve ser levado a sério porque existe uma forma de reviver isso novamente. O secretário disse que a APA veio na hora certa, pois só faz sentido uma APA onde ainda não chegou o progresso e Santo Antônio faz parte dessa positiva observação, pois se o progresso chega a qualquer hora e toma conta, não tem mais como refazer e voltar atrás.

Há um momento em que o entrevistado diz que a APA vem para preservar aquilo que pode ser destruído, mas lamentavelmente a APA não está muito clara para a sociedade. Nas escolas, nas faculdades não se houve falar em APA, as pessoas tem a impressão de que uma APA é imune, não se pode mexer mais nela, impedindo que se construa, mas não é nada disso. A APA simplesmente ordena o tipo de construção em cada região, em cada zona como é determinada.

Para Planejar a APA foram feitos estudos, participação da comunidade, mas houve discórdia de algumas pessoas em relação às categorias que foram encaixadas as zonas. O secretário declara que se existisse antes um plano diretor, talvez não existiria a APA no modo em que foi feita, pois a mesma é baseada no que o plano diretor pede hoje.

A APA foi feita com o decreto do governador, isso é uma vantagem, pois se tivesse sobre o comando do município talvez as coisas não teriam sido mais fáceis de acordo aos interesses da comunidade. Houve a idéia, as reuniões, a lei foi criada e o plano de manejo foi elaborado como deveria ser, a capacidade de carga especificada. Há uma travessia de balsa no destino e não foi feita uma ponte para ligar Cabrália ao povoado, pois assim, é uma forma de manter a capacidade de 
carga controlada, caso contrário, poderia exceder o número de visitação. Será que a região agüentaria uma quantidade excessiva de visitantes que para lá se dirigiriam? E a comunidade será que suportaria ver uma grande quantidade de turistas chegando em sua localidade, provocando barulho? É todo um ordenamento para proteger e não causar tantos impactos e a construção de uma ponte vai contra toda essa proteção.

O secretário diz que mesmo com a proteção da APA, os impactos são inevitáveis. A APA precisa ser acompanhada, infelizmente, ela não tem tido reuniões freqüentemente, a dependência do governo, dessa mudança recente não tem causado bons fluidos para o desempenho da APA, pois os grupos não têm feito as reuniões mensalmente como deveria.

Acrescenta ainda Sr. Euclides que as reuniões da APA acontecem através de conselhos em que uma pessoa é nomeada pelo Estado como gestora da APA, normalmente essa pessoa vem de Salvador. Para o entrevistado a comunidade deveria ter o direito de escolha, afinal seria mais interessante colocar como gestora da APA uma pessoa que conheça as necessidades locais, que saiba apontar as situações e deficiências recentes, que realmente capacite a reunião.

Dessa forma acontecem as reuniões, a gestora ouve os conselheiros para saber o que é bom e o que não é para a localidade. O conselho Gestor da APA decide o que será melhor. O Sr. Euclides relata 3 fases importantes das reuniões sobre a APA, a primeira fase está ligada aos ecologistas que brigavam para chamar atenção e ninguém os entendia; a segunda fase está ligada aos conselheiros que ouvem, falam se concordam ou não; a terceira fase está intimamente relacionada a apresentação de soluções para minimizar os problemas, os impactos que forem causados. É levado em discussão se um empresário tem planos de construir um hotel dentro da APA, pois é importante ouvi-lo, saber qual o seu projeto e analisar se vale a pena. É essencial a preocupação com o meio ambiente disse o entrevistado, mas meio ambiente não se resume apenas em cuidar de água, mata, passarinho, mas também o impacto sobre o homem.

Foi perguntado ao secretário sobre a existência de uma secretaria da APA, ele disse que não existe, o que na verdade existe é a gestora e uma secretária que a auxilia e faz a ata das reuniões, essa secretária pode ser indicada pelos 
conselheiros e é voluntária. Mas uma secretaria própria para cuidar da APA não existe.

Segundo Sr. Euclides os conselheiros participam das reuniões da APA e pronto "meu papel já foi cumprido", na verdade não é bem assim, não se deve arquivar a ATA das reuniões e achar que a missão está cumprida. Um problema muito sério em relação a APA, é a falta de recursos para levar as propostas adiante. As vezes uma pessoa constrói numa zona da APA que é proibida e a falta de fiscalização facilita esse tipo de acontecimento. A falta de incentivo também proporciona o mau uso da APA, muitos donos de terra constroem inadequadamente dentro de uma área de preservação, talvez se o governo proporcionasse um incentivo como por exemplo diminuir o imposto para aqueles que forem construir adequadamente e trabalhar na conservação do ambiente natural, aí sim, esse seria um grande passo rumo a sustentabilidade da APA.

Em relação ao turismo sustentável, diz o entrevistado, que pensar globalmente e agir localmente é um discurso muito bonito, mas fica no papel. Ele disse que o interessante seria colocar esse discurso em prática e que as pessoas estão mais interessadas em saber quem vai dar casa, hospital e não quem está empenhado em preservar. Para a população o turismo sustentável significa o bem-estar dela, ter saúde, educação e comida, mesmo que para sustentar isso seja preciso desmatar.

Para o Sr. Euclides a sustentabilidade é possível ser aprendida, mas muito difícil, porque hoje o homem está aprendendo na marra e não por educação, bom senso e percepção do que é importante, mas pelo sentir, pelo refletir. Uma pessoa humilde hoje que não coloca fogo na mata, ela aprendeu por si só que não estava mais dando certo, mas não foi a educação que a ensinou a ter essa atitude. Aprender sobre sustentabilidade deveria ser uma forma mais gostosa, mais prazerosa, mas essa é uma questão que não está inclusa na educação, e, será difícil de ensinar a educação mostrando que um pouquinho será tirado dos seus direitos.

Ele afirma que o país não é de oportunidades, que o povo passa necessidades, falta emprego e infelizmente essa é uma cultura que se é aprendida. Por que não discutir o meio ambiente com jeito e carinho? $\mathrm{Na}$ verdade a sustentabilidade é uma utopia, pois foi criada e não foi explicada como conduzi-la e 
se tratando de turismo sustentável, também não está sendo ensinado como promove-lo. As pessoas precisam pensar mais em suas atitudes! O turismo sustentável está sendo aprendido da mesma forma que a AIDS foi aprendida, de uma forma muito estranha ao invés de ser aprendido como uma coisa normal.

É preciso mostrar e ensinar a sociedade que o meio ambiente pode ser aprendido e entendido de uma forma muito simples, onde ela própria entenda porque o meio ambiente deve ser preservado, ter atitudes sustentáveis e a educação de casa é o melhor exemplo, é a melhor escola que o cidadão pode ter. Às vezes a falta de educação sobre o meio ambiente não está somente para os analfabetos, mas também para quem teve acesso a educação e possui uma prática de sustentabilidade muito pequena.

Se hoje for feita uma pesquisa em ralação ao turismo sustentável nos hotéis, em $90 \%$ dos resultados mostrará que não existe respeito com o meio ambiente. 0 meio natural é a peça fundamental do turismo, pois o que sustenta mesmo a execução da atividade são as belezas naturais. 


\section{APÊNDICE B}

\section{Entrevista realizada ao morador voluntário Sr. Antônio Barbosa Lacerda, sobre a preservação da APA de Santo Antônio - Ba.}

A entrevista com o Sr. Antônio Barbosa ocorreu em sua casa numa terça-feira, entre 09h e 10h do dia 30 de janeiro de 2007. A entrevista foi realizada através de uma seqüência de tópicos para obtenção dos dados adquiridos nessa pesquisa.

- Sobre a função que o voluntário exerce na proteção da APA;

- A APA de Santo Antônio e preservação dos recursos locais;

- Participação da comunidade na preservação da APA;

- Sobre a necessidade de uma Secretaria da APA de Santo Antônio;

- Como acontecem as reuniões da APA;

- Plano de Manejo da APA de Santo Antônio;

- Turismo sustentável no povoado e melhoria da qualidade de vida da comunidade local;

- Importância do planejamento turístico para o povoado.

O Sr. Antônio faz parte do da APA de Santo Antônio, ele é presidente da associação de moradores e da associação de pescadores. Iniciou a entrevista falando sobre o trabalho com a APA, ele disse que é um trabalho coletivo com todos os órgãos, o IBAMA (Instituto Brasileiro do Meio Ambiente e dos Recursos Naturais Renováveis), CRA (Centro de Recursos Ambientais) e Marinha. Todos esses órgãos competentes apóiam a proteção do meio ambiente e juntos vão trabalhar com a comunidade sobre a importância de preservar toda essa riqueza natural disponível, a fim de que futuras gerações possam ter a oportunidade de vivenciá-la.

Segundo o entrevistado, para manter esse patrimônio preservado, pessoas responsáveis e conscientes devem incentivar a comunidade local a não destruir as matas, nem poluir os rios, preservar os corais e arrecifes, pois Sr. Antônio destaca que desde a sua mocidade aos dias atuais tudo está muito diferente. 
Ele continua a entrevista dizendo que daqui há 20 anos, seus netos não terão prazer em ver e apreciar o que ele viu e apreciou. Por isso ele se preocupa tanto com a APA. O Sr. Antônio disse que se prontificou em ajudar voluntariamente na preservação da APA, sem ganho algum porque tem a certeza de que futuramente estará ganhando.

A ajuda que ele presta na preservação da APA está inteiramente relacionada à fiscalização, pois se ele ver alguém desmatando sem autorização do IBAMA, imediatamente solicita ao órgão para que tome providências necessárias. Quando isso ocorre, ele e outros colegas que trabalham juntos na preservação da APA chamam a pessoa que está cometendo 0 ato de destruição e conversa educadamente para não ter conflitos e continuar o trabalho numa boa, em união como deve ser numa comunidade.

O Sr. Antônio deixa bem claro durante a entrevista o amor que tem pelo povoado e pela diversidade ecológica disponível naquela região. Ele destaca que a vida marinha é muito frágil e não há porque prejudica-la para uso próprio do homem, sendo que quando estiver tudo no seu tempo o homem poderá usufruir de uma forma sustentável.

O entrevistado relata que quando a comunidade trabalha junto na preservação do meio ambiente, as chances de crescer e ganhar aumenta, mas quando há reunião com o conselho e que algumas pessoas não se atentam as dificuldades, ele diz que se retira da reunião consciente de que todos erram, mas para os que estão ali debatendo sobre preservar uma Área de Preservação Ambiental não obterem o mesmo senso de preservação fica difícil de levar adiante.

Em relação a secretaria da APA, o Sr. Antônio diz que foi feita uma nomeação no governo de Paulo Souto, mas devido a problemas políticos parou por aí, não houve comparecimento de mais ninguém de Salvador para as reuniões. Agora se reúnem somente os conselheiros da própria região, antes vinham representantes da Marinha, do IBAMA e do CRA no intuito de organizar melhor as coisas.

O entrevistado diz que poucas pessoas da comunidade participam das reuniões e só comparecem mesmo porque os responsáveis convocam. A cada mês a reunião acontece num local diferente, onde possam discutir com a comunidade específica de cada localidade e assim eles dão seqüência. 
Sobre o Plano de Manejo, Sr. Antônio disse que eles trabalham em cima dele juntamente com os órgãos. Quando há um ataque de desmatamento em qualquer área, seja Marinha ou IBAMA, imediatamente o voluntário entra em contato com os órgãos responsáveis pela área que está sofrendo o ataque para que tomem uma atitude. Ele ainda exemplifica que se uma obra está sendo realizada num solo proibido e sem o seu conhecimento, ele entra em contato com o IBAMA para saber se está legalizada aquela obra.

Ele fala sobre o projeto FAZENDA ONDINA que está em avaliação para ser construída nas proximidades do povoado Santo Antônio, esse projeto passa pelo conselho que 0 analisa com muito cuidado juntamente com o IBAMA e os outros órgãos, se tudo estiver corretamente legal, de acordo com as normas e exigências da lei, o mesmo estará aprovado para construção.

O entrevistado volta a falar sobre a questão do trabalho voluntário de conscientização com a população em preservar o ambiente natural e diz que é muito importante essa questão. Declara ainda que as pessoas só vêem o erro após comete-lo e quando não tem mais jeito, talvez se o enxergasse antes, as coisas seriam mais fáceis de se resolver.

Os conselheiros que trabalham nessa corrente de preservação e conservação da APA devem explicar a comunidade o porque de preservar, quais as conseqüências que ela própria poderá correr através do mau uso dos recursos ambientais.

De acordo Sr. Antônio quando uma empresa propõe implementar um negócio na região, de imediato é visto como uma novidade positiva, pois será muito bom para o desempenho financeiro da comunidade, devido à geração de empregos, mas é preciso verificar se esse negócio vai ser instalado adequadamente, vai crescer ordenadamente para não prejudicar a própria comunidade futuramente.

Sobre o turismo sustentável na região, o Sr. Antônio disse que acha uma ótima possibilidade de desenvolvimento para a população, pois o único vínculo que eles têm como fonte de emprego é o turismo.

Mas, para o Sr. Antônio antes que o turismo atue em algum lugar, ele precisa ser planejado e bem organizado, para que o turista se sinta mais a vontade e 
protegido, pois não adianta o turismo chegar e não ter estrutura. O poder público precisa ajudar, fazer reuniões com os secretários administrativos para saber o que está precisando na localidade para acolher o visitante. "Primeiramente é preciso organizar a casa para depois chamar o visitante", disse ele.

O Sr. Antônio afirmou que está de acordo com o desenvolvimento do turismo na região e que o primeiro passo a ser seguido seria organizar o que poderá ser feito e como, sem prejudicar o ambiente natural. A segurança do turista é essencial diz o voluntário, para que ele não sofra nenhum tipo de acidente devido um atrativo não estar corretamente seguro para visitação, a estrutura deve ser adequada para que tudo funcione direito.

Em comparação aos outros povoados vizinhos o entrevistado acha que o turismo seria uma fonte de riqueza para o povoado como tem acontecido no povoado de Santo André que está construindo o turista. Ele ainda diz que Santo Antônio precisa de muitas coisas e Santo André já possui muito, e que deve ser feito um plano para Santo Antônio crescer junto.

Segundo Sr. Antônio a falta de organização pode prejudicar o local e a comunidade. A comunidade deve estar ciente dos danos que o turismo pode causar por falta de planejamento, essa deve ser educada para dar exemplo aos turistas de preservação, saber observar e olhar as metas de crescimento do local.

O voluntário disse que o turismo deve ser organizado para que pessoas de fora não cheguem e ocupem o espaço dos moradores, nem mesmo para colocar empreendimento sem autorização, talvez até tirando oportunidade dos nativos.

Sr. Antônio afirma que para divulgar a localidade o primeiro passo é público, a prefeitura é responsável pelo município. Para realizar o turismo e divulgar o povoado, o poder público deve se reunir com os conselheiros e os órgãos da APA para decidir qual a melhor forma de realizar um plano de desenvolvimento, afinal de contas as condições para este acontecimento são oferecidas pela prefeitura. Se não houver interesse do município será muito difícil de acontecer o desenvolvimento do turismo no povoado. O esforço de todos juntos poderá facilitar as coisas para que aconteçam corretamente, seguir em frente e procurar entender os planos da APA, caminhar junto com aqueles que entendem melhor do assunto e de proteção ambiental para que o patrimônio seja utilizado adequadamente. 


\section{APÊNDICE C}

Entrevista realizada em 2005 por essa pesquisadora sobre o povoado de Santo Antônio, com Sr. prefeito de Santa Cruz Cabrália - Ba, Sr. José Ubaldino Alves Pinto.

A entrevista com o prefeito de Santa Cruz Cabrália, ocorreu em sua residência, no mês de setembro em 2005. Também foram utilizados tópicos para a seqüência da entrevista.

- Sobre o povoado Santo Antônio;

- Turismo na região;

- Turismo no povoado;

- Parque Ecológico O Santuário;

- Construção da Estátua de Santo Antônio;

- Sobre a festa de Santo Antônio;

- Projetos voltados para o desenvolvimento de Santo Antônio;

- Melhoramento da infra-estrutura do povoado.

O Sr. Prefeito José Ubaldino Alves Pinto, conhecido como Bahiano, fala da paixão pelo povoado, pois já morou em vários lugares do país, mas nenhum ele considera tão espetacular como Santo Antônio.

O sr. prefeito, considera que a região tem um potencial muito grande para 0 turismo ecológico, e está sendo descoberta agora. Ele ressalta o Rio Santo Antônio como uma grande riqueza, que é bem protegida com $67 \mathrm{Km}$ de mata atlântica, o Rio João de Tiba também tem um grande potencial na região. O povoado de Santo Antônio não teve ainda a oportunidade de se desenvolver como o povoado de Santo André, pois este está localizado diretamente na orla marítima, enquanto que Santo Antônio, não está diretamente em frente ao mar, há um manguezal, entre o rio navegável para a prática do turismo e o mar. 
Então, o prefeito aponta a região com um grande potencial para o futuro turístico. Ele faz um breve comentário sobre o projeto de Coroa Alta, voltado para a hotelaria "serão construídos cinco hotéis de médio porte do turismo internacional". Ele considera um grande avanço para o desenvolvimento do povoado e região. Fala ainda, sobre o investimento na hotelaria de um grupo francês e português no povoado de Mogiquissaba e Guaiú, há 14 km de Santo Antônio.

Foi questionado a Bahiano, o porque do fechamento do Parque Ecológico $O$ Santuário. Segundo ele "o Parque foi fechado devido a uma enchente muito grande que derrubou as passarelas, caiu muita madeira, o rio ficou muito sinuoso e apertado evitando assim o movimento de chalana e barco". Mas já está sendo reformado para voltar a funcionar, pois ele acredita que o Parque Ecológico tem um grande potencial, pois apresenta características naturais, como $12 \mathrm{~km}$ de rio navegável, animais silvestres, situado numa área de mata atlântica.

Segundo Bahiano Santo Antônio terá grande influência turística. Recentemente foi construída no próprio povoado a Estátua de Santo Antônio inaugurada no dia 30 de Julho de 2005. É considerada a maior estátua de Santo Antônio do mundo com 15,50 metros de altura, e ainda ao lado do Santo está uma pequena capela para maior apreciação da comunidade e visitantes. A área de localização da estátua é na fazenda Santuário, que pertence ao Sr. prefeito Bahiano, proporcionando assim uma visão de longa distância do Santo.

No decorrer da entrevista, Bahiano fala sobre sua devoção ao Santo Antônio, pois reconhece que a intenção de viver no povoado e de se apaixonar pelo local, a ponto de não querer sair, foi uma força muito grande do Santo Antônio. Sentiu a necessidade de homenagear o povoado e poder encontrar um lugar seguro par se viver.

A partir daí, conta o entrevistado, foi onde percebeu que a construção do Santo seria a maior homenagem que poderia fazer ao Rio Santo Antônio, ao povoado e ao Santo Antônio. A data de comemoração do Santo será no dia 3 de Junho, pois é data oficial do Santo. O prefeito abordou o projeto que tem para a festa de Santo Antônio, o qual retrata da seguinte forma: Será feita a trezena de Santo Antônio, treze dias de festa nos povoados circunvizinhos, com o encerramento em Santo Antônio. A intenção da prefeitura é realizar uma festa bem regional, mas também 
relacionada ao dia 12 de Junho que é dia dos namorados, e segundo Bahiano o Santo Antônio representa o amor, a felicidade.

Ele pretende fazer a festa do dia $1^{\circ}$ ao dia $13^{\circ}$ de Junho, evitando assim o São João porque já acontece em todo lugar. Pretende realizar um festival de prêmios aos maiores forrozeiros do Brasil, leilões, cavalgadas, participação de trios elétricos, enfim, ele ressalta dizendo que a festa de Santo Antônio será o carro chefe da região em eventos na região. Há ainda uma idéia de realizar no encerramento da festa no povoado de Santo Antônio o casamento coletivo, realizado pela igreja católica, onde os pretendentes deverão fazer a inscrição antes para o acontecimento. De acordo o prefeito já foi conversado com o padre e o mesmo achou a idéia fantástica.

$\mathrm{Na}$ intenção de atrair o turismo para o local, será divulgada a festa em rede de tv, e apontou a TV Diário porque tem uma grande influência com o povo nordestino. O projeto já está pretendido para o ano 2006, e já estão sendo tomadas todas as providências para acontecimento do mesmo.

Mas, segundo Bahiano, ainda há outros projetos voltados para o desenvolvimento, do povoado e região, que podem influenciar no potencial turístico que o local oferece e que precisa por em prática.

Um dos projetos que ele destacou foi à construção de um aeroporto internacional no município de Cabrália, pois em Porto Seguro não tem área suficiente. Esse é um aspecto muito positivo, pois através do aeroporto internacional, conseqüentemente o povoado irá se desenvolver turisticamente. Bahiano revela que projetos de infra-estrutura estão sendo elaborados para serem implementados, a fim de ocasionar melhores mudanças no povoado.

Esse é um ponto muito importante para o turismo, pois atrai mais turistas, os locais bem estruturados e organizados. O visitante não vai querer sair de seu local de moradia para um destino turístico que não possa usufruir do conforto $e$ facilidades, e é nesse ponto que a infra-estrutura pode atuar para o desenvolvimento do local.

O prefeito tem planos de construir um centro comunitário para reunir famílias, desenvolver a prática de esportes, favorecer o interesse da comunidade pelo teatro, espaço para shows, enfim uma espécie de clube, o qual terá o nome de Baiódromo. 
Segundo o prefeito esse nome foi escolhido, devido ao seu apelido Bahiano e por ser um local para eventos como o Sambódromo.

Tem a intenção de investir na saúde, construindo um hospital pequeno com maternidade, o qual será o centro de atendimento não somente de Santo Antônio, mas também para os outros povoados vizinhos.

De acordo aos projetos da prefeitura em relação ao turismo, o prefeito conseguiu através do juiz e promotor, a liberação da área para o acesso a praia, pois é uma área de preservação ambiental que deve ser usufruída com muito cuidado. Pretende divulgar o povoado pela rodovia através de placas em toda a região que tem fluxo turístico.

Em janeiro de 2006, já tem a intenção de colocar o projeto de melhoramento da infra-estrutura em prática (saneamento, o cais do Rio, construção de um colégio com 5 salas e um campo de futebol, a creche). Mas o prefeito deixa bem claro que para desenvolver o turismo no povoado é indispensável à participação da comunidade, enfim, o turismo é a integração com a comunidade, e é isso que prevalece.

A prefeitura de Cabrália está disponibilizando cursos de aperfeiçoamento para a comunidade local e região, os cursos são oferecidos pela AGENDEC, a fim de dar oportunidades empregatícias, pois segundo Bahiano só a prefeitura não tem como empregar toda a comunidade da região. Essa é uma questão muito importante porque favorece a população no mercado de trabalho. 


\section{APÊNDICE D}

\section{Entrevista realizada em 2005 por essa pesquisadora com a secretária do turismo de Santa Cruz Cabrália - Ba, Sra. Amale Abou Jokh, sobre o turismo em Santo Antônio.}

Foi realizada uma entrevista no dia 19 de Julho de 2005 à secretária do turismo de Cabrália Sra. Amale Abou Jokh, a qual realizou-se através de tópicos para adquirir os dados da pesquisa.

- Sobre o povoado Santo Antônio;

- Atuação do turismo no povoado;

- Turismo sustentável na APA de Santo Antônio;

- Infra-estrutura do povoado para o turismo;

- Esforços da Secretaria de Turismo para melhor desempenho do turismo na região.

A secretária iniciou a entrevista sobre o povoado de Santo Antônio. Ela mencionou no início da entrevista, que precisa existir um projeto para o desenvolvimento do turismo de Santo Antônio. E, segundo a entrevistada, o primeiro passo para a realização desse seria a conscientização da população em relação ao turismo.

Segundo Sra. Amale deve-se formar uma equipe composta por moradores, onde possa trabalhar a consciência do que venha a ser o turismo. Para reforçar a idéia, ela fala sobre a distribuição de uma cartilha à comunidade, no intuito de que essa tenha conhecimento educacional sobre o turismo, e a intenção é começar pelas escolas.

Um outro aspecto muito importante apontado na conversa foi sobre a preocupação que eles têm em proteger a APA de Santo Antônio. Pretende trabalhar com o turismo sustentável e um público selecionado para isso. Seria um turismo voltado completamente à natureza, o turismo ecológico. Amale também deixa claro a preocupação com a preservação da cultura local, e antes de tudo é necessário 
trabalhar o turismo em relação a isso, para que não venha interferir no modo de vida da população.

De acordo Amale, é preciso melhorar a infra-estrutura do povoado, a intenção é começar pela reforma da praça, construção do cais do Rio Santo Antônio, pois para que o turismo se desenvolva em determinado lugar é preciso ter a estrutura adequada para tal atividade. A secretária fala sobre o acesso ao povoado, pois Santo André está mais próximo, vem logo após a balsa e isso facilita o desenvolvimento do turismo local. Porém, Santo Antônio fica localizado depois de Santo André e por isso o acesso aos turistas é mais difícil, mas a região está sendo descoberta agora.

A secretaria do turismo de Cabrália pretende trabalhar a regionalização da Costa do Descobrimento, a fim de abranger ainda mais o futuro turístico. 
ANEXOS 
ANEXO A

\section{Fotos da APA de Santo Antônio.}

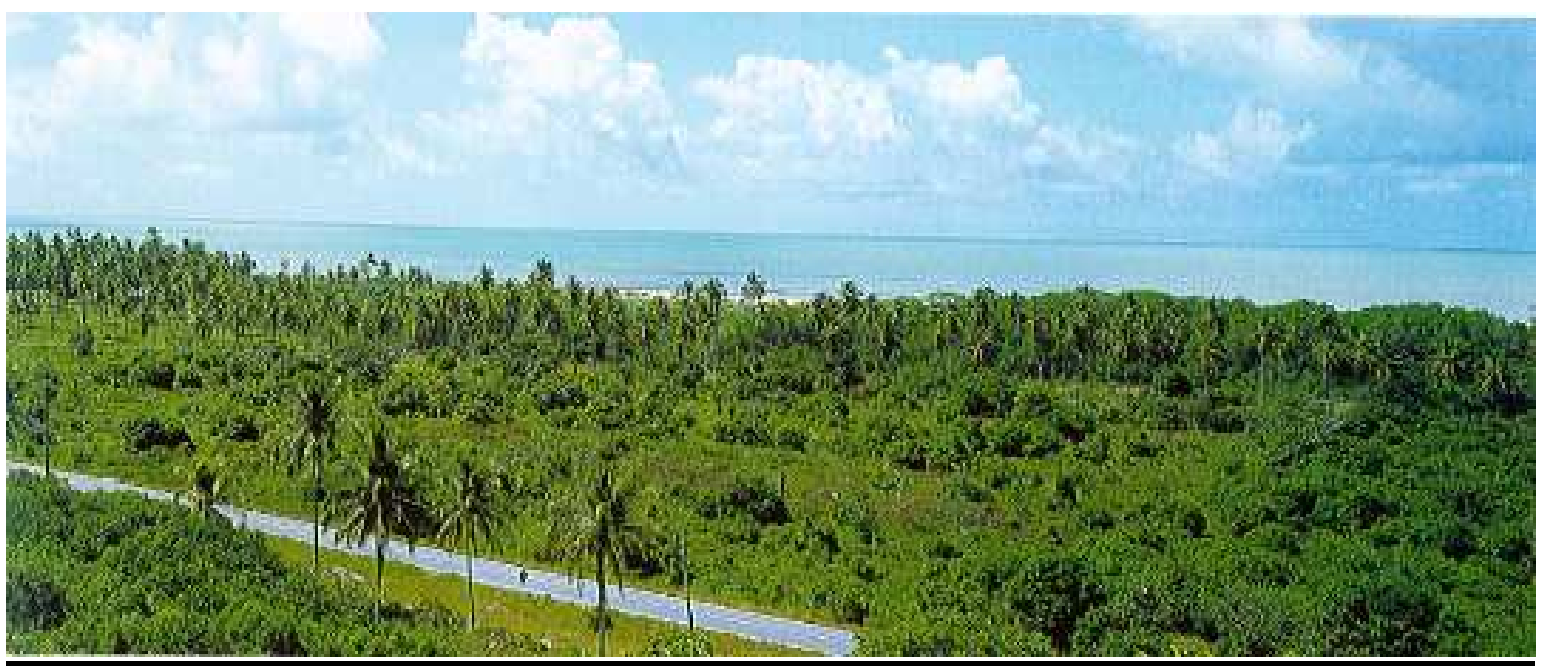

Figura 1: Foto da APA de Santo Antônio (Rodovia BA 001). Fonte: Plano de Manejo da APA de Santo Antônio, 1999.

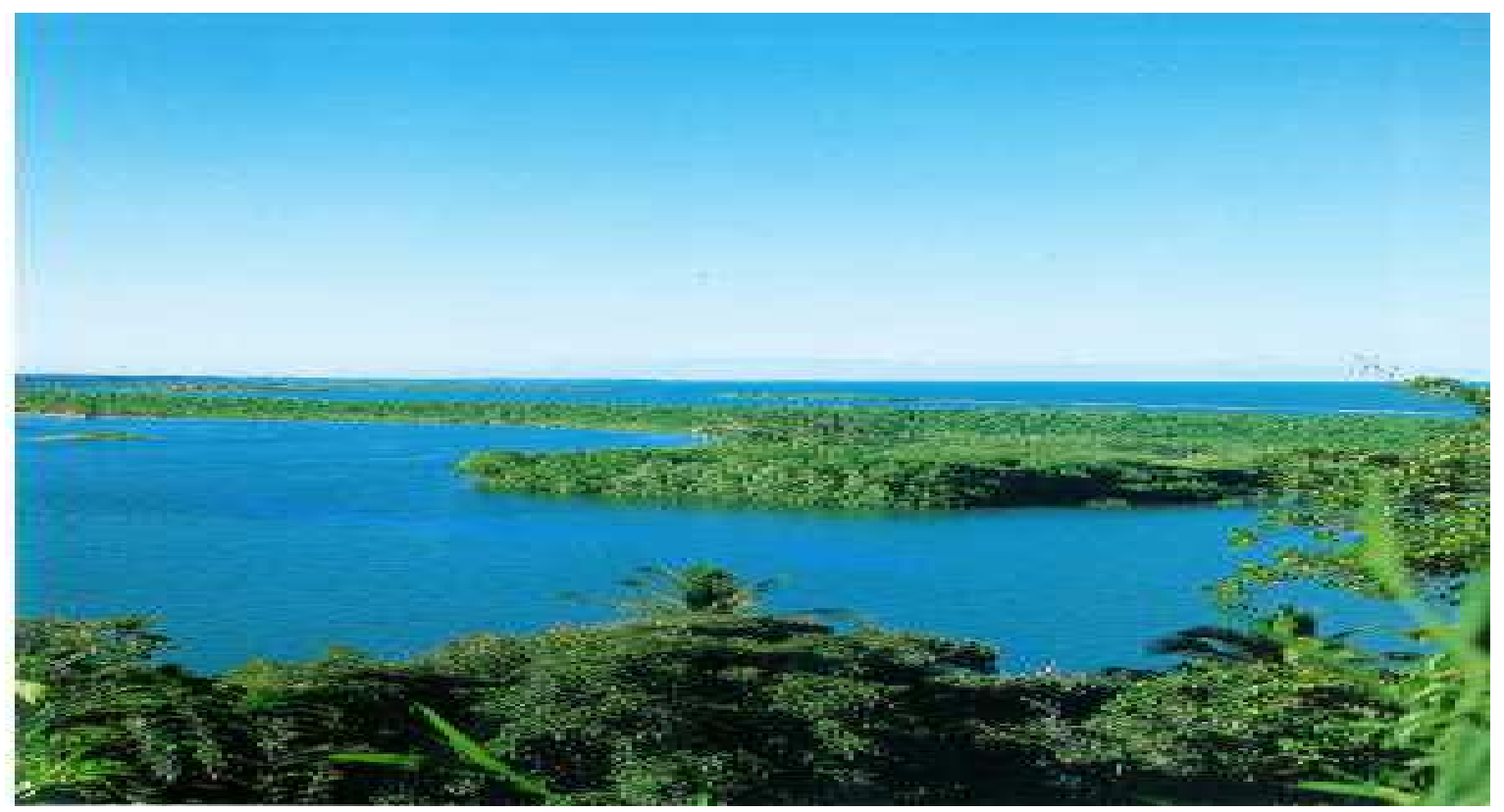

Figura 2: Foto da APA, ilustração do Rio João de Tiba. Fonte: Plano de Manejo da APA de Santo Antônio, 1999. 


\section{Fotos da APA de Santo Antônio e dos atrativos turísticos}

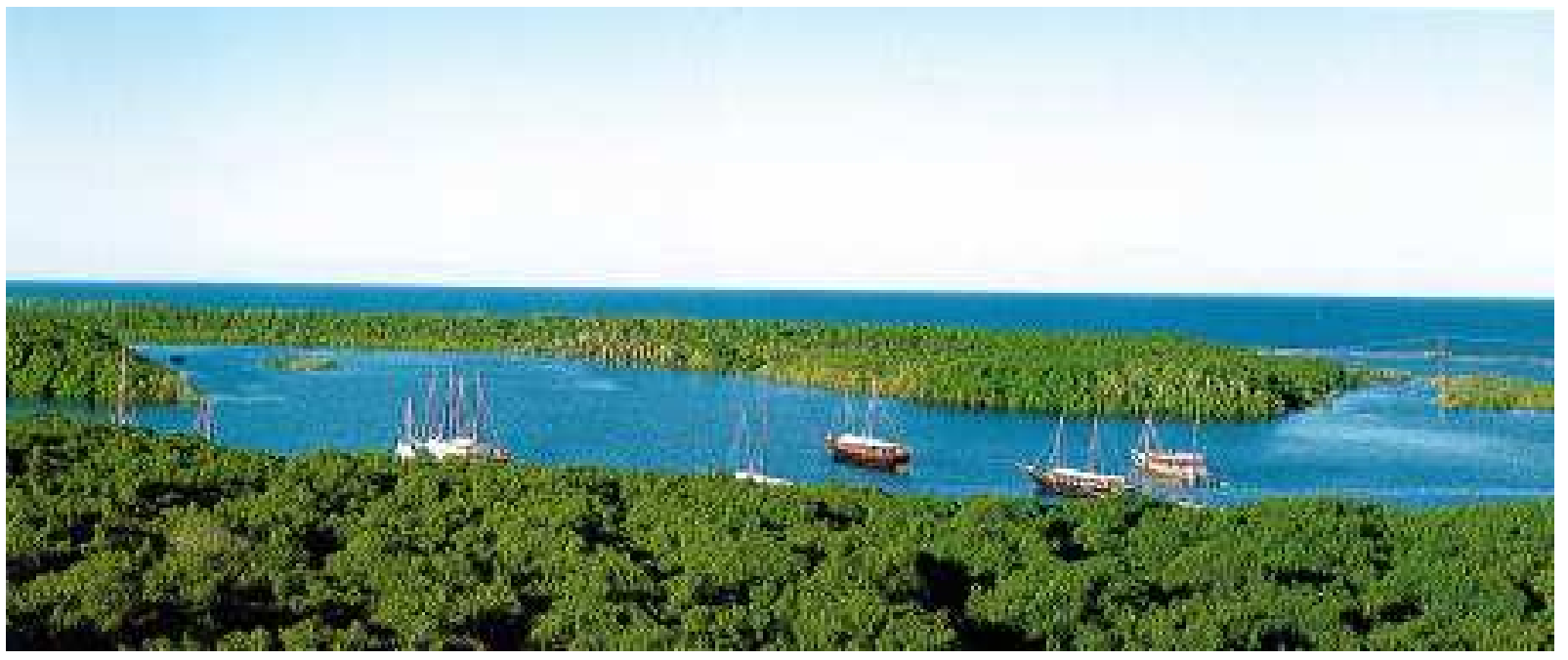

Figura 3: Foto do Rio João de Tiba, próximo ao povoado Santo Antônio (Passeio de Escunas pelo rio).

Fonte: Plano de Manejo da APA de Santo Antônio, 1999.

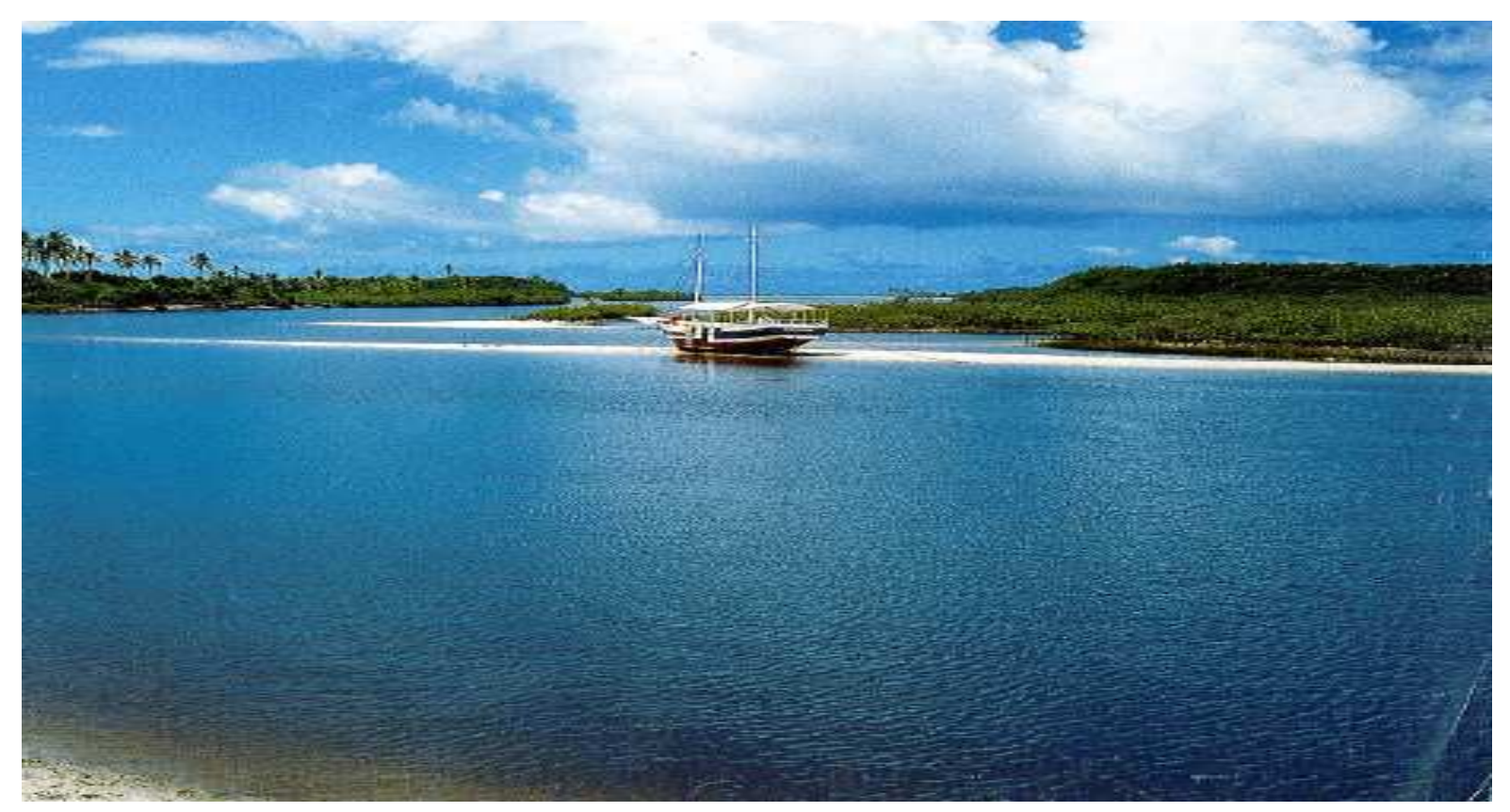

Figura 4: Foto do Rio Santo Antônio e mangue.

Fonte: Plano de Manejo da APA de Santo Antônio, 1999. 


\section{Fotos dos atrativos turísticos de Santo Antônio}

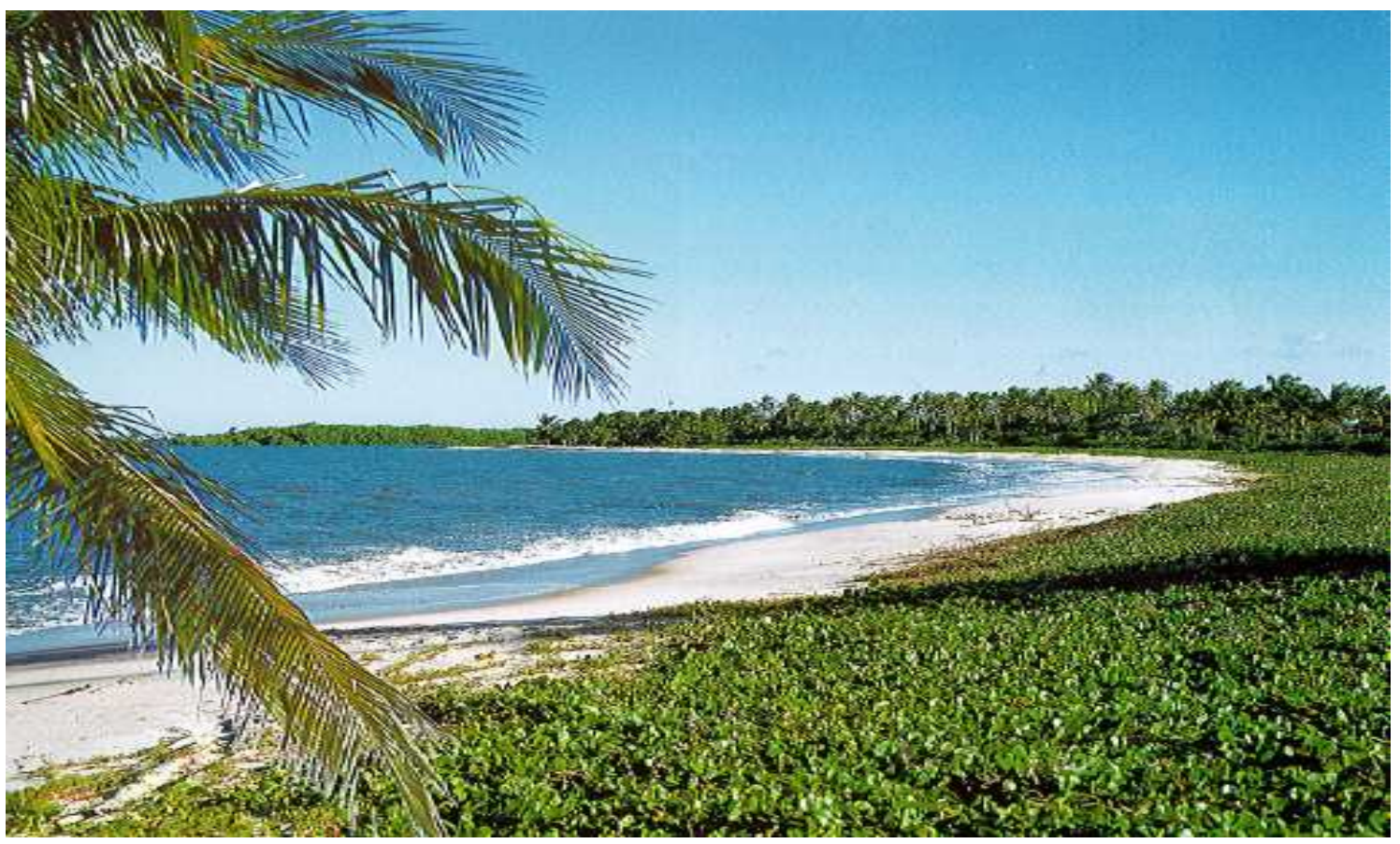

Figura 5: Foto da Praia de Santo Antônio e Restinga.

Fonte: Plano de Manejo da APA de Santo Antônio, 1999.

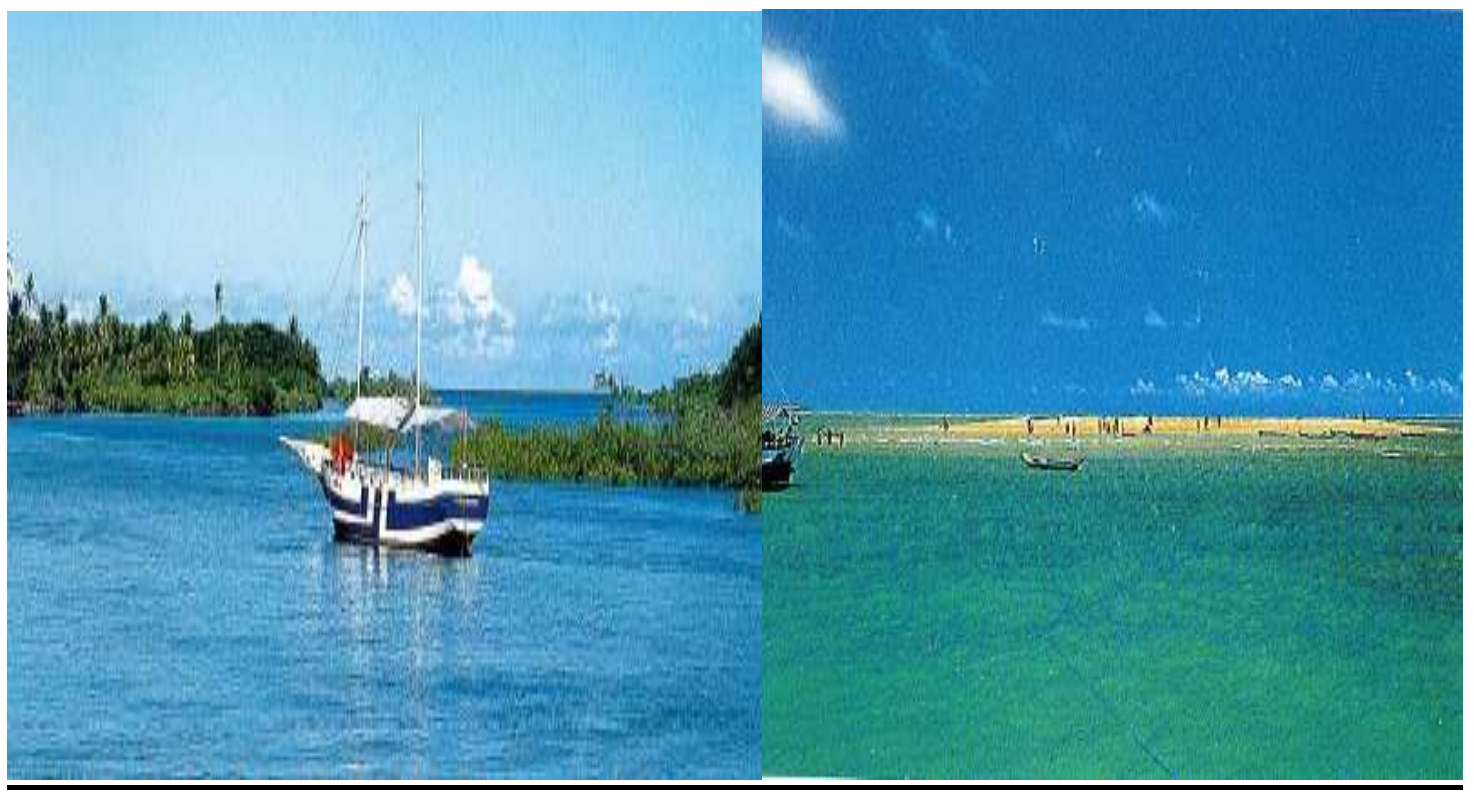

Figura 6: Foto do Rio Santo Antônio. Foto da llha Coroa Alta.

Fonte: Plano de Manejo da APA de Santo Antônio, 1999. 
Fotos da APA de Santo Antônio e atrativos turísticos

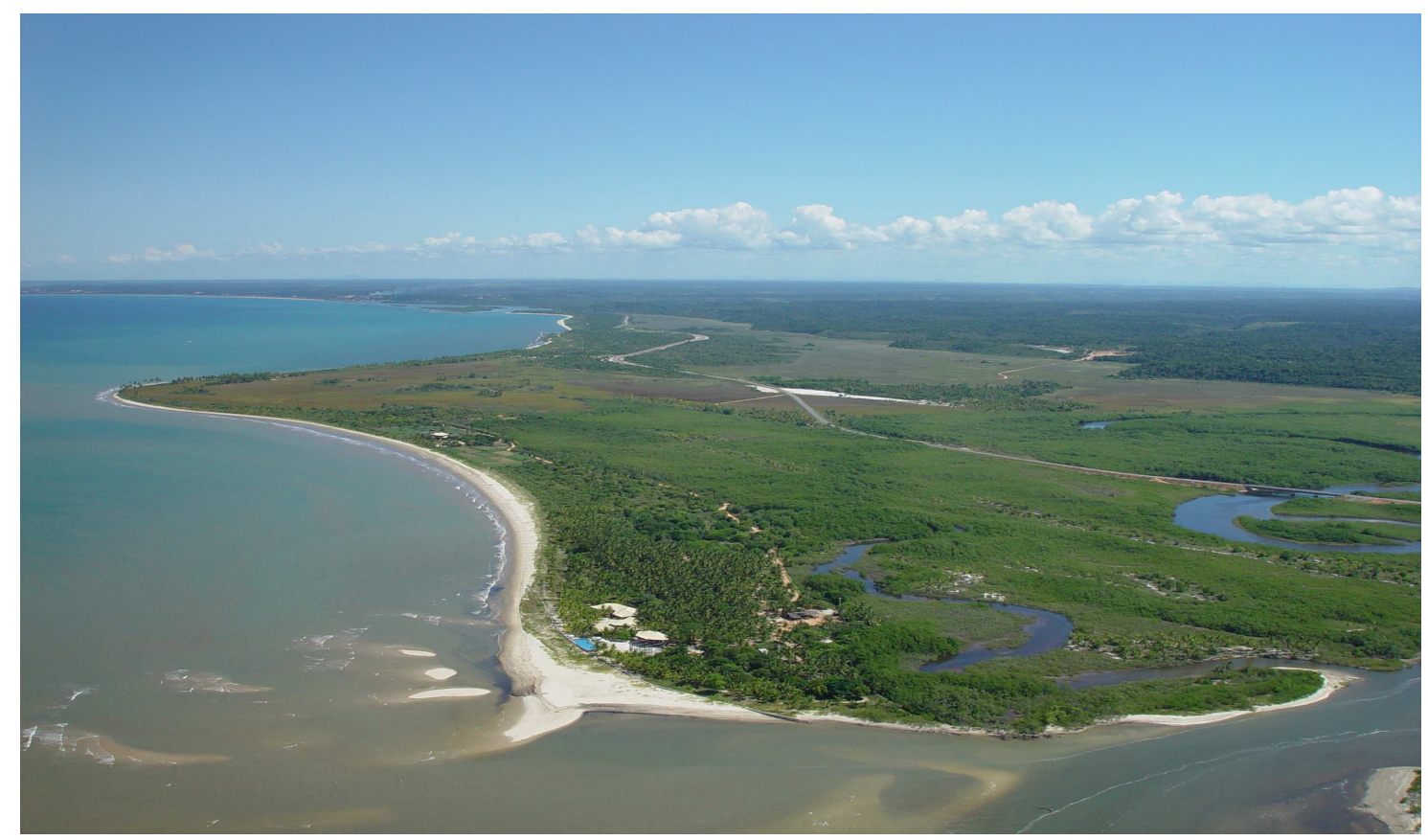

Figura 7: Foto aérea do Povoado Santo Antônio

Fonte: Secretaria do Turismo de Santa Cruz Cabrália- Ba, 2005.

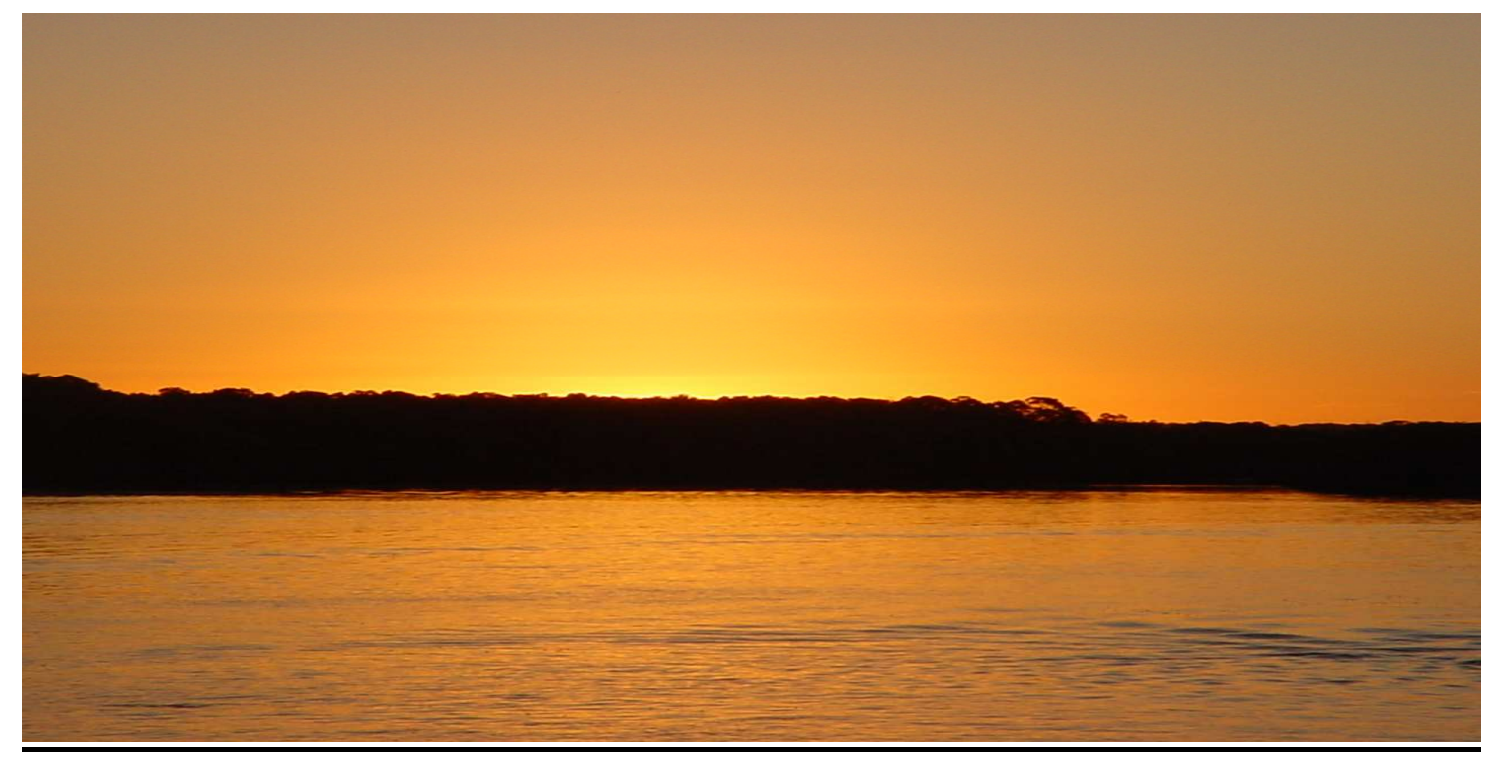

Figura 8: Foto do Rio Santo Antônio

Fonte: Secretaria de Turismo de Santa Cruz Cabrália - Ba, 2005. 
Anexo B

Mapa do Plano de Manejo da APA de Santo Antônio.

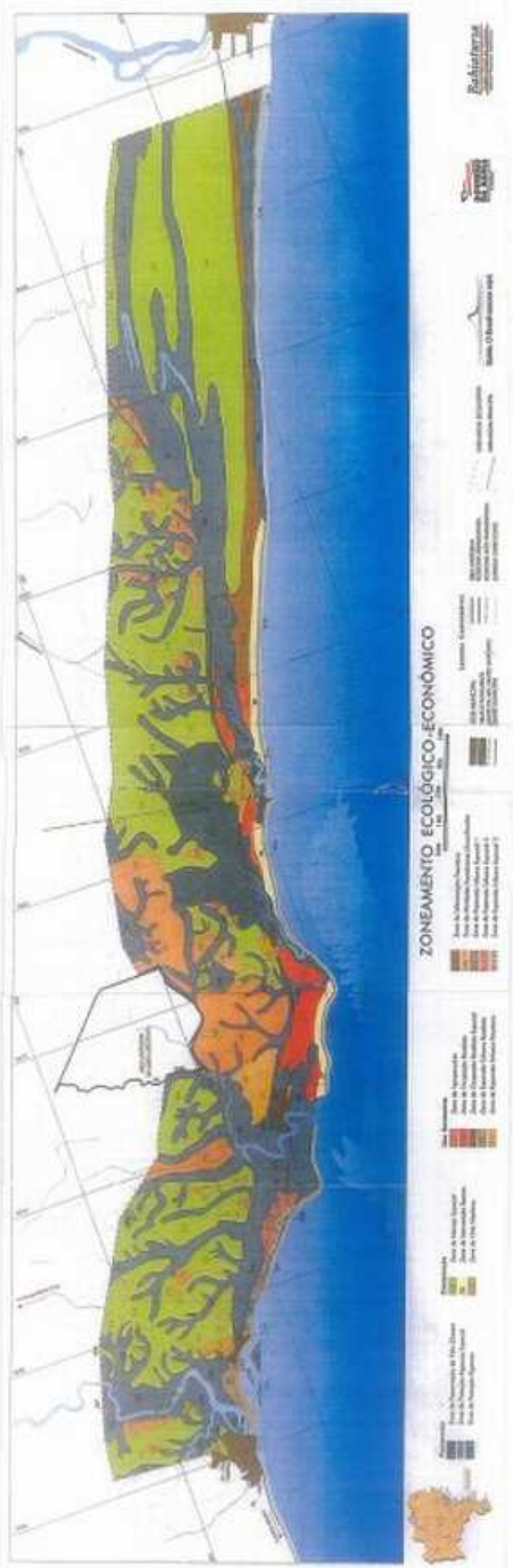

Figura 9: Mapa da APA de Santo Antônio

Fonte: Plano de Manejo da APA de Santo Antônio, 1999. 